with a modified version of the LTEX class copernicus.cls.

Date: 2 May 2008

\title{
Supplement to: Cloud system resolving model study of the roles of deep convection for photo-chemistry in the TOGA COARE/CEPEX region
}

\author{
M. Salzmann, M. G. Lawrence, V. T. J. Phillips, and L. J. Donner
}

\section{Description of the CSRMC}

\subsection{Meteorological component}

The meteorological component of the CSRMC is based on a modified height coordinate prototype version of the nonhydrostatic, compressible Weather and Research and Forecasting (WRF) model. The WRF model is a community model which is being developed in a collaborative effort by the National Center for Atmospheric Research (NCAR), the National Centers for Environmental Prediction (NCEP), the Air Force Weather Agency, Oklahoma University, and other partners. It has been designed as a regional model which is capable of operating at high resolutions. The source code as well as additional information can be obtained from the WRF model web site at http://wrf-model.org. The basic equations of the height coordinate version can be found in Skamarock et al. (2001) and the numerics are described in Wicker and Skamarock (2002).

In the present study microphysical processes are parameterized using a single-moment scheme (Lin et al., 1983) which is not part of the WRF model distribution. The scheme is described by Krueger et al. (1995) and is based on Lord et al. (1984). Hydrometeor- and tracer mass mixing ratios are transported using the Walcek (2000) monotonic advection scheme instead of the third order Runge-Kutta scheme which was originally implemented in the WRF model prototype. For solving the momentum equations and the theta equation, the third order Runge-Kutta scheme is used in combination with fifth/third order spatial discretizations for horizontal/vertical advection terms. Shortwave radiation is parameterized using the Goddard shortwave scheme (Chou et al., 1998), and the RRTM scheme (Mlawer et al., 1997) is used for parameterizing longwave radiation in our simulations. Subgrid scale turbulence is parameterized applying Smagorinsky's closure scheme (e.g. Takemi and Rotunno, 2003). The meteorological component of the CSRMC has previously been used in Salzmann et al. (2004, 2007).

1.2 Meteorological setup and vertical large scale advection tendencies for tracers (VLSAT)

The meteorological setup is based on the "SLBC \& VLSAT" setup of Salzmann et al. (2004); i.e., vertical and horizontal large scale advection tendencies for potential temperature, vertical large scale advection tendencies for trace gases (VLSAT) and for water vapor, and specified lateral boundary conditions (SLBC) for trace gases and water vapor are applied. The large scale advection (LSA) tendencies for potential temperature and water vapor can be expressed as:

$$
\begin{aligned}
\left.\partial_{t} \bar{\theta}\right|_{L S} & =\quad-\overline{\mathbf{v}}_{h} \cdot \nabla \bar{\theta}-\bar{w} \partial_{z} \bar{\theta} \\
\left.\partial_{t} \bar{q}_{v}\right|_{L S} & =-\bar{w} \partial_{z} \bar{q}_{v}
\end{aligned}
$$

where overbars denote horizontal domain averages, and $\mathbf{v}_{h}=(u, v)$ is the horizontal wind vector. Note that for water vapor horizontal LSA tendencies are omitted since lateral boundary conditions are specified. The terms on the right hand side of Eqs. 1 and 2 are specified from observations based on data from Ciesielski et al. (2003).

The average horizontal wind is nudged towards observations (data from Ciesielski et al., 2003):

$$
\left.\partial_{t} \overline{\mathbf{v}}_{h}\right|_{L S}=-\left(\overline{\mathbf{v}}_{h}-\overline{\mathbf{v}}_{h, o b s}\right) / \tau_{a d j}
$$

where $\mathbf{v}_{h}=(u, v)$, as in e.g. Xu and Randall (1996) and Johnson et al. (2002) with an adjustment time $\tau_{a d j}=1 \mathrm{~h}$.

For tracers a method of accounting for large scale vertical ascent is used which was previously used for $q$ and $\theta$ by Xu and Randall (1996); Xu and Krueger (1991):

$$
\left.\partial_{t} \mu\right|_{L S}=-\bar{w}_{\text {obs }} \partial_{z} \mu
$$

where $\mu$ is the modeled tracer mixing ratio and $\bar{w}_{\text {obs }}$ is the average vertical velocity derived from observations (see Ciesielski et al., 2003). For a detailed discussion of these choices see Salzmann et al. (2004). 


\subsubsection{Numerical aspects of calculating VLSAT}

In the present study periodic boundary conditions are applied to air mass, i.e., air mass is not allowed to enter the model domain through the domain's lateral boundaries and the observed mean vertical velocity $\bar{w}_{\text {obs }}$ is not used to advect the air mass inside the model domain. Equation (4), on the other hand, is formulated for a tracer which is advected with the flow. Unfortunately, this formulation does not easily allow a simultaneously mass conserving and monotonic solution. Sensitivity runs solving Eq. (4) for inert tracers and periodic boundary conditions (e.g. using the scheme by Walcek, 2000) in fact yield small mass changes which tend to be maximum in the UT. The usual method to avoid mass errors would be to numerically solve Eq. (4) starting from its flux form:

$$
\partial_{t} C=-\partial_{z}\left(\bar{w}_{o b s} C\right)
$$

where $C=\rho \mu$ is the tracer concentration. For transforming Eq. (4) to flux form the mass continuity equation for $\bar{w}_{\text {obs }}$ has to be applied. In the model, however, the (3-D) mass continuity equation for $\bar{w}_{\text {obs }}$ is not solved. As a consequence, using a flux form of Eq. (4) (or neglecting changes of the dimensional densities in the Walcek (2000) scheme) can lead to a non-monotonic solution for the tracer's mixing ratio. Since Eq. (4) is a 1D advection problem with a divergent wind field, using the flux form (Eq. (5)) implies that tracer mass can locally be either accumulated (in the case of convergence) or depleted (in the case of divergence), resulting in non-monotonic, and in the case of VLSAT non-physical solutions for the mixing ratios. For tracers with a 'smooth' vertical profile such as CO this can have important effects, while the idealized tracers in Salzmann et al. (2004) are only weakly affected. In the present study this problem was addressed by solving Eq. (4), which is in advective form (preserving monotonicity), and then scaling the solution such that the column mass change during the calculation must be balanced by the vertically integrated flux divergence due to $\bar{w}_{o b s}$ up to the height $z_{m}=19.5 \mathrm{~km}$. The scale factor $f$ is defined by the condition that the finite-difference equivalent of

$$
\begin{aligned}
& f\left(\int_{0}^{z_{m}} \rho \mu \mathrm{dz}+\Delta t \int_{0}^{z_{m}} \rho \bar{w}_{o b s} \partial_{z} \mu \mathrm{dz}\right) \\
& =\int_{0}^{z_{m}} \rho \mu \mathrm{dz}+\Delta t \int_{0}^{z_{m}} \partial_{z}\left(\rho \bar{w}_{o b s} \mu\right) \mathrm{dz}
\end{aligned}
$$

must hold. The integral which is part of the second term on the right hand side of Eq. (6) equals the column tracer mass change per unit area due to $\bar{w}_{o b s}$ calculated from the flux form tracer continuity equation. The value of this integral depends on $z_{m}$ and decreases rapidly to comparatively low, but generally non-zero values above the tropopause as a consequence of small, but positive $\bar{w}_{o b s}$ in the lower stratosphere. The scaled solution is very similar to the non-scaled solution of Eq. (4). However, scaling can in principle introduce undesired features (see e.g. Jöckel et al., 2001) and should be avoided. A very simple solution to this problem would be to neglect the influence of the mean vertical velocity on the vertical advection of trace gases, as was done previously by Lu et al. (2000). This leads, however, to a considerable overestimation of the role of the mesoscale subsidence, as was shown by Salzmann et al. (2004).

\subsection{Photochemistry}

The photochemistry mechanism (Table 1) is based on von Kuhlmann et al. (2003a), and references therein. It is a "background" $\mathrm{CH}_{4}-\mathrm{CO}-\mathrm{HO}_{\mathrm{x}}-\mathrm{NO}_{\mathrm{x}}$ tropospheric chemistry mechanism (reactions $\mathrm{R} 1-\mathrm{R} 46)$ with additional reactions involving PAN (R47-R60) and loss reactions of acetone (R61 and R62). The photodissociation of $\mathrm{HNO}_{4}$ in the nearIR (e.g. Roehl et al., 2002, and references therein) was included in the CSRMC based on Roehl et al. (2002) who suggested a daytime near-IR photolysis rate of approximately $1 \cdot 10^{-5} \mathrm{~s}^{-1}$. In the CSRMC, the clear sky photolysis rate for $\mathrm{NO}_{3}\left(\mathrm{~J}_{10}\right.$ in R34) as calculated for the first day of the TOGA COARE simulation was scaled by the factor $4.5 \cdot 10^{-5}$ to approximately yield $1 \cdot 10^{-5} \mathrm{~s}^{-1}$ (see R63).

The KPP (Kinetic PreProcessor; Damian-Iordache, 1996; Damian et al., 2002; Sander et al., 2005) symbolic preprocessor has been coupled to the WRF-based CSRMC and a threestage Rosenbrock solver (e.g. Hairer and Wanner, 1996) is used to numerically integrate the chemistry equations forward in time. KPP is a computer program which reads reactions and reaction rates from an input file provided by the user and writes the program code necessary to perform the numerical integration. The syntax of the input file is similar to the syntax used in Table 1. Furthermore, in WRF new variables are specified in an ASCII table and the part of the code which is responsible for memory management and inand output (IO) is written by preprocessors. An additional preprocessor was constructed for the CSRMC which writes the interface between the WRF code and the KPP generated code. The pre-processors are automatically applied prior to the compilation of the model code. This setup considerably reduces the effort necessary to include new chemical compounds and/or reactions into the CSRMC, and has lately been adapted for the WRF-Chem community model (Grell et al., 2005).

Photolysis rates are computed every 5 minutes using the computationally efficient scheme by Landgraf and Crutzen (1998). In this scheme, the rates are computed using a parameterization for a purely absorbing atmosphere at eight representative wavelengths. Then corrections for the effects of clouds, aerosols, and molecular scattering are added. Cloud water paths are calculated from modeled hydrometeor concentrations, currently treating hydrometeors in both the ice and in the liquid phase as liquid phase hydrometeors. For aerosols, a constant background distribution and optical properties typical of marine aerosols are assumed. 
Table 1: Gas phase reactions

\begin{tabular}{|c|c|c|c|}
\hline No. & Reaction $^{1,2}$ & Rate $^{3}$ & Ref. \\
\hline R1 & $\mathrm{O}_{3}+\mathrm{h} \nu \rightarrow \mathrm{O}\left({ }^{1} \mathrm{D}\right)+\mathrm{O}_{2}$ & $\mathrm{~J}_{1}$ & $\mathrm{~L}+\mathrm{C} 98$ \\
\hline R2 & $\begin{aligned} \mathrm{O}\left({ }^{1} \mathrm{D}\right)+\mathrm{O}_{2}(\rightarrow \mathrm{O} & \left.\left({ }^{3} \mathrm{P}\right)+\mathrm{O}_{2}^{\star}\right) \\
& \stackrel{+\mathrm{O}_{2}}{\longrightarrow} \mathrm{O}_{3}\left(+\mathrm{O}_{2}^{\star}\right)\end{aligned}$ & $\mathrm{k}_{2}=3.2 \cdot 10^{-11} \exp (70 / \mathrm{T})$ & JPL97 \\
\hline R3 & $\begin{aligned} & \mathrm{O}\left({ }^{1} \mathrm{D}\right)+\mathrm{N}_{2}(\rightarrow \mathrm{O}\left.\left({ }^{3} \mathrm{P}\right)+\mathrm{N}_{2}^{\star}\right) \\
& \stackrel{+\mathrm{O}_{2}}{\longrightarrow} \mathrm{O}_{3}\left(+\mathrm{N}_{2}^{\star}\right)\end{aligned}$ & $\mathrm{k}_{3}=1.8 \cdot 10^{-11} \exp (110 / \mathrm{T})$ & JPL97 \\
\hline R4 & $\mathrm{O}\left({ }^{1} \mathrm{D}\right)+\mathrm{H}_{2} \mathrm{O} \rightarrow 2 \mathrm{OH}$ & $\mathrm{k}_{4}=2.2 \cdot 10^{-10}$ & JPL97 \\
\hline R5 & $\mathrm{O}_{2}+\mathrm{h} \nu\left(\rightarrow 2 \mathrm{O}\left({ }^{3} \mathrm{P}\right)\right) \stackrel{+2 \mathrm{O}_{2}}{\longrightarrow} 2 \mathrm{O}_{3}$ & $\mathrm{~J}_{2}$ & $\mathrm{~L}+\mathrm{C} 98$ \\
\hline R6 & $\mathrm{O}_{3}+\mathrm{OH} \rightarrow \mathrm{HO}_{2}+\mathrm{O}_{2}$ & $\mathrm{k}_{6}=1.5 \cdot 10^{-12} \exp (-880 / \mathrm{T})$ & JPL00 \\
\hline R7 & $\mathrm{O}_{3}+\mathrm{HO}_{2} \rightarrow \mathrm{OH}+2 \mathrm{O}_{2}$ & $\mathrm{k}_{7}=2.0 \cdot 10^{-14} \exp (-680 / \mathrm{T})$ & JPL00 \\
\hline R8 & $\mathrm{HO}_{2}+\mathrm{OH} \rightarrow \mathrm{H}_{2} \mathrm{O}+\mathrm{O}_{2}$ & $\mathrm{k}_{8}=4.8 \cdot 10^{-11} \exp (250 / \mathrm{T})$ & JPLO0 \\
\hline R9 & $\mathrm{HO}_{2}+\mathrm{HO}_{2} \rightarrow \mathrm{H}_{2} \mathrm{O}_{2}+\mathrm{O}_{2}$ & $\mathrm{k}_{9}=$ complex, $\mathrm{f}\left(\mathrm{T},[\mathrm{M}],\left[\mathrm{H}_{2} \mathrm{O}\right]\right)$ & JPL97 \\
\hline R10 & $\mathrm{H}_{2} \mathrm{O}_{2}+\mathrm{h} \nu \rightarrow 2 \mathrm{OH}$ & $\mathrm{J}_{3}$ & \\
\hline R11 & $\mathrm{H}_{2} \mathrm{O}_{2}+\mathrm{OH} \rightarrow \mathrm{HO}_{2}+\mathrm{HO}_{2}$ & $\mathrm{k}_{11}=2.9 \cdot 10^{-12} \exp (-160 / \mathrm{T})$ & JPL97 \\
\hline R12 & $\mathrm{CO}+\mathrm{OH} \rightarrow \mathrm{HO}_{2}+\mathrm{CO}_{2}$ & $\mathrm{k}_{12}=1.5 \cdot 10^{-13}(1+0.6 \mathrm{P}(\mathrm{atm}))$ & JPL97 \\
\hline $\mathrm{R} 13$ & $\mathrm{CH}_{4}+\mathrm{OH} \rightarrow \mathrm{CH}_{3} \mathrm{O}_{2}+\mathrm{H}_{2} \mathrm{O}$ & $\begin{aligned} \mathrm{k}_{13}= & 2.8 \cdot 10^{-14} \mathrm{~T}^{0.667} \\
& \exp (-1575 / \mathrm{T})\end{aligned}$ & JPL97 \\
\hline R14 & $\mathrm{CH}_{3} \mathrm{O}_{2}+\mathrm{HO}_{2} \rightarrow \mathrm{CH}_{3} \mathrm{O}_{2} \mathrm{H}+\mathrm{O}_{2}$ & $\mathrm{k}_{14}=4.15 \cdot 10^{-13} \exp (750 / \mathrm{T})$ & Tyn01 \\
\hline R15 & $\mathrm{CH}_{3} \mathrm{O}_{2}+\mathrm{NO} \rightarrow \mathrm{HCHO}+\mathrm{HO}_{2}+\mathrm{NO}_{2}$ & $\mathrm{k}_{15}=2.8 \cdot 10^{-12} \exp (300 / \mathrm{T})$ & Tyn01 \\
\hline R16 & $\mathrm{CH}_{3} \mathrm{O}_{2}+\mathrm{CH}_{3} \mathrm{O}_{2} \rightarrow 2 \mathrm{HCHO}+2 \mathrm{HO}_{2}$ & $\begin{array}{l}\mathrm{k}_{16}=9.5 \cdot 10^{-14} \exp (390 / \mathrm{T}) \\
\quad /(1+1 /(26.2 \exp (-1130 / \mathrm{T})))\end{array}$ & Tyn01 \\
\hline R17 & $\mathrm{CH}_{3} \mathrm{O}_{2}+\mathrm{CH}_{3} \mathrm{O}_{2} \rightarrow \mathrm{HCHO}+\mathrm{CH}_{3} \mathrm{OH}$ & $\begin{aligned} & \mathrm{k}_{17}=9.5 \cdot 10^{-14} \exp (390 / \mathrm{T}) \\
& \quad /(1+26.2 \exp (-1130 / \mathrm{T}))\end{aligned}$ & Tyn01 \\
\hline R18 & $\mathrm{CH}_{3} \mathrm{O}_{2}+\mathrm{NO}_{3} \rightarrow \mathrm{HCHO}+\mathrm{HO}_{2}+\mathrm{NO}_{2}$ & $\mathrm{k}_{18}=1.3 \cdot 10^{-12}$ & Atk99 \\
\hline R19 & $\mathrm{CH}_{3} \mathrm{O}_{2} \mathrm{H}+\mathrm{h} \nu \rightarrow \mathrm{HCHO}+\mathrm{HO}_{2}+\mathrm{OH}$ & $\mathrm{J}_{4}$ & $\mathrm{~L}+\mathrm{C} 98$ \\
\hline $\mathrm{R} 20$ & $\begin{array}{l}\mathrm{CH}_{3} \mathrm{O}_{2} \mathrm{H}+\mathrm{OH} \rightarrow 0.7 \mathrm{CH}_{3} \mathrm{O}_{2}+0.3 \mathrm{HCHO} \\
\quad+0.3 \mathrm{OH}+\mathrm{H}_{2} \mathrm{O}\end{array}$ & $\mathrm{k}_{20}=3.8 \cdot 10^{-12} \exp (200 / \mathrm{T})$ & JPL97 \\
\hline R21 & $\mathrm{HCHO}+\mathrm{h} \nu \stackrel{+2 \mathrm{O}_{2}}{\longrightarrow} \mathrm{CO}+2 \mathrm{HO}_{2}$ & $\mathrm{~J}_{5}$ & $\mathrm{~L}+\mathrm{C} 98$ \\
\hline R22 & $\mathrm{HCHO}+\mathrm{h} \nu \rightarrow \mathrm{CO}+\mathrm{H}_{2}$ & $\mathrm{~J}_{6}$ & $\mathrm{~L}+\mathrm{C} 98$ \\
\hline R23 & $\mathrm{HCHO}+\mathrm{OH} \rightarrow \mathrm{CO}+\mathrm{HO}_{2}+\mathrm{H}_{2} \mathrm{O}$ & $\mathrm{k}_{23}=1.0 \cdot 10^{-11}$ & JPL97 \\
\hline R24 & $\mathrm{HCHO}+\mathrm{NO}_{3} \rightarrow \mathrm{CO}+\mathrm{HO}_{2}+\mathrm{HNO}_{3}$ & $\mathrm{k}_{24}=3.4 \cdot 10^{-13} \exp (-1900 / \mathrm{T})$ & JPL97 \\
\hline R25 & $\mathrm{NO}+\mathrm{O}_{3} \rightarrow \mathrm{NO}_{2}+\mathrm{O}_{2}$ & $\mathrm{k}_{25}=3.0 \cdot 10^{-12} \exp (-1500 / \mathrm{T})$ & JPL97 \\
\hline R26 & $\mathrm{NO}+\mathrm{HO}_{2} \rightarrow \mathrm{NO}_{2}+\mathrm{OH}$ & $\mathrm{k}_{26}=3.5 \cdot 10^{-12} \exp (250 / \mathrm{T})$ & JPL97 \\
\hline R27 & $\mathrm{NO}_{2}+\mathrm{h} \nu \stackrel{+\mathrm{O}_{2}}{\longrightarrow} \mathrm{NO}+\mathrm{O}_{3}$ & $\mathrm{~J}_{7}$ & $\mathrm{~L}+\mathrm{C} 98$ \\
\hline R28 & $\mathrm{NO}_{2}+\mathrm{O}_{3} \rightarrow \mathrm{NO}_{3}$ & $\mathrm{k}_{28}=1.2 \cdot 10^{-13} \exp (-2450 / \mathrm{T})$ & JPL97 \\
\hline R29 & $\mathrm{NO}_{2}+\mathrm{OH}+\mathrm{M} \rightarrow \mathrm{HNO}_{3}+\mathrm{M}$ & $\mathrm{k}_{29}=$ complex & Dra99 \\
\hline R30 & $\mathrm{NO}_{2}+\mathrm{HO}_{2}+\mathrm{M} \rightarrow \mathrm{HNO}_{4}+\mathrm{M}$ & $\mathrm{k}_{30}=$ complex & \\
\hline R31 & $\mathrm{HNO}_{3}+\mathrm{h} \nu \rightarrow \mathrm{OH}+\mathrm{NO}_{2}$ & $\mathrm{~J}_{8}$ & $\mathrm{~L}+\mathrm{C} 98$ \\
\hline R32 & $\mathrm{HNO}_{3}+\mathrm{OH}+\mathrm{M} \rightarrow \mathrm{NO}_{3}+\mathrm{H}_{2} \mathrm{O}+\mathrm{M}$ & $\mathrm{k}_{32}=$ complex & JPL00 \\
\hline R33 & $\mathrm{NO}_{3}+\mathrm{h} \nu \stackrel{+\mathrm{O}_{2}}{\longrightarrow} \mathrm{NO}_{2}+\mathrm{O}_{3}$ & $\mathrm{~J}_{9}$ & $\mathrm{~L}+\mathrm{C} 98$ \\
\hline R34 & $\mathrm{NO}_{3}+\mathrm{h} \nu \rightarrow \mathrm{NO}$ & $\mathrm{J}_{10}$ & $\mathrm{~L}+\mathrm{C} 98$ \\
\hline R35 & $\mathrm{NO}_{3}+\mathrm{NO} \rightarrow 2 \mathrm{NO}_{2}$ & $\mathrm{k}_{35}=1.5 \cdot 10^{-11} \exp (170 / \mathrm{T})$ & JPL99 \\
\hline R36 & $\mathrm{NO}_{3}+\mathrm{NO}_{2}+\mathrm{M} \rightarrow \mathrm{N}_{2} \mathrm{O}_{5}+\mathrm{M}$ & $\mathrm{k}_{36}=$ complex & JPL00 \\
\hline R37 & $\mathrm{N}_{2} \mathrm{O}_{5}+\mathrm{h} \nu \rightarrow \mathrm{NO}_{3}+\mathrm{NO}_{2}$ & $\mathrm{~J}_{11}$ & $\mathrm{~L}+\mathrm{C} 98$ \\
\hline R38 & $\begin{array}{l}\mathrm{NO}_{3}+\mathrm{HO}_{2} \rightarrow 0.8 \mathrm{NO}_{2}+0.8 \mathrm{OH} \\
+0.2 \mathrm{HNO}_{3}\end{array}$ & $\mathrm{k}_{38}=3.5 \cdot 10^{-12}$ & JPL97 \\
\hline R39 & $\mathrm{N}_{2} \mathrm{O}_{5}+\mathrm{M} \rightarrow \mathrm{NO}_{3}+\mathrm{NO}_{2}+\mathrm{M}$ & $\mathrm{k}_{39}=\mathrm{k}_{36} /\left(3 \cdot 10^{-27} \exp (10991 / \mathrm{T})\right)$ & JPL00 \\
\hline R40 & $\mathrm{N}_{2} \mathrm{O}_{5}+\mathrm{H}_{2} \mathrm{O} \rightarrow 2 \mathrm{HNO}_{3}$ & $\mathrm{k}_{40}=$ complex & $\mathrm{D}+\mathrm{C} 93$ \\
\hline R41 & $\mathrm{N}_{2} \mathrm{O}_{5}+\mathrm{H}_{2} \mathrm{O} \rightarrow 2 \mathrm{HNO}_{3}$ & $\mathrm{k}_{41}=2.5 \cdot 10^{-22}+1.8 \cdot 10^{-39}\left[\mathrm{H}_{2} \mathrm{O}\right]$ & Wah98 \\
\hline
\end{tabular}




\begin{tabular}{|c|c|c|c|}
\hline \multicolumn{4}{|c|}{ Table 1 continued } \\
\hline R42 & $\begin{array}{l}\mathrm{HNO}_{4}+\mathrm{h} \nu \rightarrow 0.39 \mathrm{NO}_{3}+0.39 \mathrm{OH} \\
\quad+0.61 \mathrm{NO}_{2}+0.61 \mathrm{HO}_{2}\end{array}$ & $\mathrm{~J}_{12}$ & $\begin{array}{r}\mathrm{L}+\mathrm{C} 98, \\
\text { Atk97 }\end{array}$ \\
\hline R43 & $\mathrm{HNO}_{4}+\mathrm{M} \rightarrow \mathrm{HO}_{2}+\mathrm{NO}_{2}+\mathrm{M}$ & $\mathrm{k}_{43}=\mathrm{k}_{30} /\left(2.1 \cdot 10^{-27} \exp (10900 / \mathrm{T})\right)$ & JPL97 \\
\hline R44 & $\mathrm{HNO}_{4}+\mathrm{OH} \rightarrow \mathrm{NO}_{2}+\mathrm{H}_{2} \mathrm{O}+\mathrm{O}_{2}$ & $1.3 \cdot 10^{-12} \exp (380 / \mathrm{T})$ & JPL97 \\
\hline R45 & $\mathrm{H}_{2}+\mathrm{OH} \rightarrow \mathrm{HO}_{2}+\mathrm{H}_{2} \mathrm{O}$ & $\mathrm{k}_{45}=5.5 \cdot 10^{-12} \exp (-2000 / \mathrm{T})$ & JPL97 \\
\hline R46 & $\mathrm{CH}_{3} \mathrm{OH}+\mathrm{OH} \rightarrow \mathrm{HCHO}+\mathrm{HO}_{2}$ & $\mathrm{k}_{46}=6.7 \cdot 10^{-12} \exp (600 / \mathrm{T})$ & JPL97 \\
\hline R47 & $\mathrm{CH}_{3} \mathrm{CO}_{3}+\mathrm{HO}_{2} \rightarrow \mathrm{CH}_{3} \mathrm{CO}_{3} \mathrm{H}$ & $\begin{array}{r}\mathrm{k}_{47}=4.3 \cdot 10^{-13} \exp (1040 / \mathrm{T}) \\
(1+1 /(37 \exp (-660 / \mathrm{T})))\end{array}$ & Tyn01 \\
\hline R48 & $\mathrm{CH}_{3} \mathrm{CO}_{3}+\mathrm{HO}_{2} \rightarrow \mathrm{CH}_{3} \mathrm{COOH}+\mathrm{O}_{3}$ & $\begin{array}{l}\mathrm{k}_{48}=4.3 \cdot 10^{-13} \exp (1040 / \mathrm{T}) \\
\quad(1+37 \exp (-660 / \mathrm{T}))\end{array}$ & Tyn01 \\
\hline R49 & $\mathrm{CH}_{3} \mathrm{CO}_{3}+\mathrm{NO} \rightarrow \mathrm{CH}_{3} \mathrm{O}_{2}+\mathrm{NO}_{2}+\mathrm{CO}_{2}$ & $\mathrm{k}_{49}=8.1 \cdot 10^{-12} \exp (270 / \mathrm{T})$ & Tyn01 \\
\hline R50 & $\mathrm{CH}_{3} \mathrm{CO}_{3}+\mathrm{NO}_{2} \rightarrow \mathrm{PAN}$ & $\mathrm{k}_{50}=$ complex & Tyn01 \\
\hline R51 & $\begin{array}{l}\mathrm{CH}_{3} \mathrm{CO}_{3}+\mathrm{CH}_{3} \mathrm{O}_{2} \\
\quad+\mathrm{CH}_{3} \mathrm{O}_{2}+\mathrm{CO}_{2}\end{array}$ & $\begin{array}{l}\mathrm{k}_{51}=2.0 \cdot 10^{-12} \exp (500 / \mathrm{T}) / \\
\quad\left(1+1 /\left(2.2 \cdot 10^{6} \exp (3820 / \mathrm{T})\right)\right)\end{array}$ & $\begin{array}{l}\text { Tyn01, } \\
\text { JPL97 }\end{array}$ \\
\hline R52 & $\begin{array}{l}\mathrm{CH}_{3} \mathrm{CO}_{3}+\mathrm{CH}_{3} \mathrm{O}_{2} \rightarrow \mathrm{CH}_{3} \mathrm{COOH} \\
\quad+\mathrm{HCOH}+\mathrm{CO}_{2}\end{array}$ & $\begin{array}{l}\mathrm{k}_{52}=2.0 \cdot 10^{-12} \exp (500 / \mathrm{T}) / \\
\left(1+2.2 \cdot 10^{6} \exp (-3820 / \mathrm{T})\right)\end{array}$ & $\begin{array}{l}\text { Tyn01, } \\
\text { JPL97 }\end{array}$ \\
\hline R53 & $\begin{array}{l}\mathrm{CH}_{3} \mathrm{CO}_{3}+\mathrm{CH}_{3} \mathrm{CO}_{3} \rightarrow 2 \mathrm{CH}_{3} \mathrm{O}_{2}+2 \mathrm{CO}_{2} \\
\quad+\mathrm{O}_{2}\end{array}$ & $\mathrm{k}_{53}=2.5 \cdot 10^{-12} \exp (500 / \mathrm{T})$ & Tyn01 \\
\hline R54 & $\mathrm{CH}_{3} \mathrm{CO}_{3}+\mathrm{NO}_{3} \rightarrow \mathrm{CH}_{3} \mathrm{O}_{2}+\mathrm{NO}_{2}+\mathrm{CO}_{2}$ & $\mathrm{k}_{54}=4 \cdot 10^{-12}$ & Tyn01 \\
\hline R55 & $\mathrm{CH}_{3} \mathrm{CO}_{3} \mathrm{H}+\mathrm{h} \nu \rightarrow \mathrm{CH}_{3} \mathrm{O}_{2}+\mathrm{OH}$ & $\mathrm{J}_{13}=0.025 \mathrm{~J}_{5}$ & RvK01 \\
\hline R56 & $\mathrm{CH}_{3} \mathrm{CO}_{3} \mathrm{H}+\mathrm{OH} \rightarrow \mathrm{CH}_{3} \mathrm{CO}_{3}$ & $\mathrm{k}_{56}=\mathrm{k}_{20}$ & \\
\hline R57 & $\mathrm{PAN}+\mathrm{OH} \rightarrow \mathrm{HCHO}+\mathrm{NO}_{2}+\mathrm{CO}_{2}$ & $\mathrm{k}_{57}=2 \cdot 10^{-14}$ & JPL97 ${ }^{4}$ \\
\hline R58 & $\mathrm{PAN}+\mathrm{h} \nu \rightarrow \mathrm{CH}_{3} \mathrm{CO}_{3}+\mathrm{NO}_{2}$ & $\mathrm{~J}_{14}$ & $\begin{array}{r}\mathrm{RvK} 01, \\
\mathrm{~L}+\mathrm{C} 98\end{array}$ \\
\hline R59 & $\mathrm{PAN}+\mathrm{M} \rightarrow \mathrm{CH}_{3} \mathrm{CO}_{3}+\mathrm{NO}_{2}$ & $\begin{array}{l}\mathrm{k}_{59}=\mathrm{k}_{50} / 9 \cdot 10^{-29} \\
\quad \exp (-14000 / \mathrm{T})\end{array}$ & JPL97 \\
\hline R60 & $\mathrm{CH}_{3} \mathrm{COOH}+\mathrm{OH} \rightarrow \mathrm{CH}_{3} \mathrm{O}_{2}+\mathrm{CO}_{2}$ & $\mathrm{k}_{60}=4 \cdot 10^{-13} \exp (200 / \mathrm{T})$ & JPL97 \\
\hline R61 & $\mathrm{CH}_{3} \mathrm{COCH}_{3}+\mathrm{h} \nu \rightarrow \mathrm{CH}_{3} \mathrm{CO}_{3}+\mathrm{CH}_{3} \mathrm{O}_{2}$ & $\mathrm{~J}_{15}$ & $\begin{array}{r}\mathrm{RvK} 01, \\
\mathrm{~L}+\mathrm{C} 98\end{array}$ \\
\hline R62 & $\mathrm{CH}_{3} \mathrm{COCH}_{3}+\mathrm{OH} \rightarrow \mathrm{CH}_{3} \mathrm{COOH}+\mathrm{CH}_{3} \mathrm{O}_{2}$ & $\mathrm{k}_{62}=1.7 \cdot 10^{-14} \exp (423 / \mathrm{T})$ & Wol00 \\
\hline R63 & $\mathrm{HNO}_{4}+\mathrm{h} \nu \rightarrow \mathrm{HO}_{2}+\mathrm{NO}_{2}$ & $\mathrm{~J}_{15}=4.5 \cdot 10^{-5} \mathrm{~J}_{10}$ & $\begin{array}{l}\text { see } \\
\text { text }\end{array}$ \\
\hline
\end{tabular}

References: JPL00 is Sander et al. (2000), JPL97 is DeMore et al. (1997), Tyn01 is Tyndall et al. (2001), L+C98 is Landgraf and Crutzen (1998), Atk99 is Atkinson et al. (1999), Atk97 is Atkinson et al. (1997), Dra99 is Dransfield et al. (1999), D+C93 is Dentener and Crutzen (1993), Wah98 is Wahner et al. (1998), RvK01 is von Kuhlmann (2001), Wol00 is Wollenhaupt et al. (2000) and Wollenhaupt and Crowley (2000).

Notes: ${ }^{1}$ Where appropriate, several reactions have been summarized as one step.

2 Changes of $\mathrm{O}_{2}, \mathrm{H}_{2} \mathrm{O}, \mathrm{CO}_{2}$, and $\mathrm{H}_{2}$ concentrations due to chemical reactions are not considered in the CSRMC.

3 For first-, second-, and third- order reactions, the units of the rate coefficients $\mathrm{k}$ are $\mathrm{s}^{-1}$, $\mathrm{cm}^{3}$ molecule $\mathrm{s}^{-1} \mathrm{~s}^{-1}$, and $\mathrm{cm}^{6}$ molecule $\mathrm{s}^{-1}$. The units of the photolysis rates $\mathrm{J}$ are $\mathrm{s}^{-1}$.

4 One half of the maximum rate constant given in DeMore et al. (1997) is used.

Some of the photolysis rates needed in the CSRMC were not calculated in the original scheme. Von Kuhlmann (2001) extended the scheme making use of correlations between these newly added photolysis rates and photolysis rates already calculated in the original scheme. 3-D radiation effects are not considered in the scheme by Landgraf and Crutzen. The radiative transfer is calculated using the $\delta$-two stream model by Zdunkowski et al. (1982).
1.4 Algorithms for identifying updrafts and anvils in the flash parameterization

The WRF-based CSRMC is designed with the capability of running on distributed memory parallel platforms such as Linux clusters. For this purpose the domain can be decomposed horizontally into smaller sub-domains and distributed over a number of processors. In order to minimize the amount of communication between processors, we first cal- 

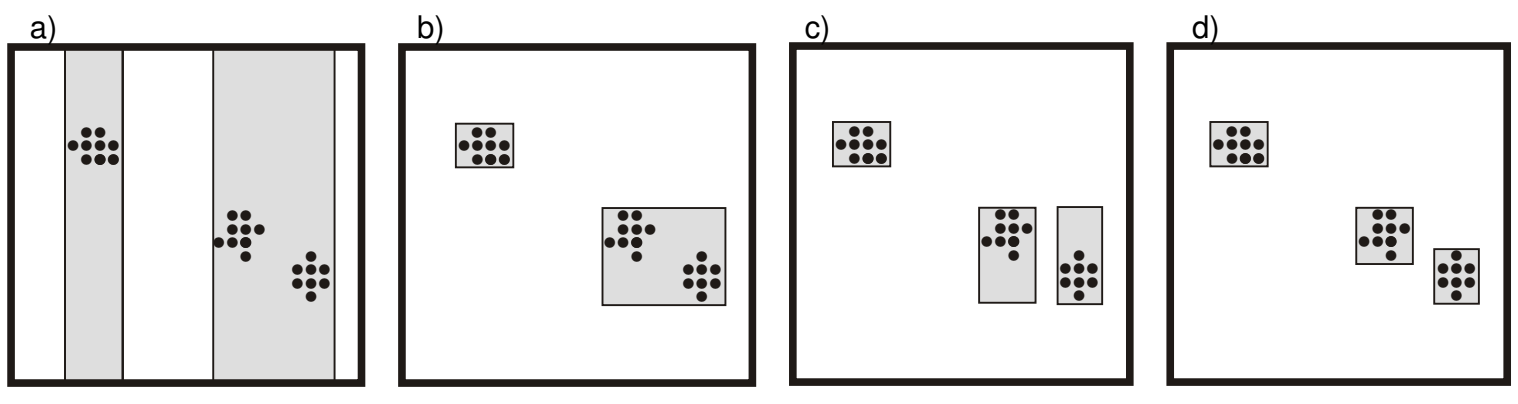

Fig. 1. Schematic: Identification of updrafts by fitting rectangles in the X-Y plane. Dots represent flagged points where the vertical velocity exceeds $5 \mathrm{~m} \mathrm{~s}^{-1}$ and the total hydrometeor mass mixing ratio exceeds $0.1 \mathrm{~g} \mathrm{~kg}^{-1}$ at at least one point in the corresponding grid column. The domain is scanned in alternating directions. (a) Rectangles (grey shaded) after the first scan (in x-direction); (b) after the second scan (in y-direction); (c-d) after subsequent scans.

culate 2-D fields of column maximum vertical velocity, cloud top height (as defined in Sect. M2.1 of the manuscript), etc., which are then gathered by one of the processors in a single array using the so-called WRF Communication Application Program Interface (Comm-API).

The algorithm for identifying updrafts is similar to Friedel et al. (1997), i.e., larger rectangles containing columns with points where $w>5 \mathrm{~m} \mathrm{~s}^{-1}$ and $q_{\text {totm }}>0.01 \mathrm{~g} \mathrm{~kg}^{-1}$ (where $q_{\text {totm }}=q_{\text {cloudwater }}+q_{\text {rain }}+q_{\text {ice }}+q_{\text {graupel }}+q_{\text {snow }}$ is the sum of all hydrometeor mass mixing ratios) are recursively cut into smaller rectangles until no new edges are found with $w_{\text {max }} \leq 5 \mathrm{~ms}^{-1}$ everywhere (see schematic in Fig. 1). For each of the resulting rectangles the point with the maximum vertical velocity is identified.

Starting from these points we identify anvils as follows (compare code excerpt on the following page): First all grid points in the entire domain with a cloud top height $z_{c t}$ between $z_{c t w}-1400 \mathrm{~m}$ and $z_{c t w}+1400 \mathrm{~m}$ are flagged (where $z_{c t w}$ has been defined as the cloud top height at the location of the maximum vertical updraft velocity). Then, one grid point wide connections between flagged regions ("bridges") and single points ("bumps") on the edges of the flagged regions are removed. Finally, all the flagged points are identified which lie inside the region where the column with the maximum updraft velocity is located. This fairly simple method allows us to assign anvils to the updrafts which have previously been identified by fitting rectangles as described above.

\subsection{Soluble trace gases}

For soluble trace gases the uptake by, release from, sedimentation together with, and mass transfer between different model categories of hydrometeors in the liquid or ice phase are calculated as in Salzmann et al. (2007). Concentrations of dissolved trace gases and gases taken up by the ice phase are treated as prognostic variables (i.e. they undergo transport and parameterized turbulence). The rate of change of the gas phase concentration $C_{g}$ due to uptake/release of a tracer by/from hydrometeors is

$$
\left.\partial_{t} C_{g}\right|_{h y}=-\sum_{j=1}^{5}\left(\left.\partial_{t} C_{j}\right|_{m t}-\left.\partial_{t} C_{j}\right|_{e v, s u}\right),
$$

where $\left.\partial_{t} C_{j}\right|_{m t}$ is the rate for the mass transfer between hydrometeors of category $j$ and the gas phase (for release $\left.\partial_{t} C_{j}\right|_{m t}<0$ ), and $\left.\partial_{t} C_{j}\right|_{e v, s u}$ is the source rate due to the evaporation or sublimation of hydrometeors of model category $j$. Here concentrations are defined as tracer mass per grid box volume. $\left.\partial_{t} C_{j}\right|_{e v, s u}$ is zero unless hydrometeors of a certain category entirely evaporate or sublimate during an integration timestep. In this case, the tracer is assumed to be completely released to the gas phase (aerosol effects, in particular sticking to the condensation nucleus are not considered). The rate of change (in addition to advection and turbulence) of the concentration $C_{j}$ of a tracer taken up by hydrometeors of model category $j$ is

$$
\left.\partial_{t} C_{j}\right|_{h y}=\left.\partial_{t} C_{j}\right|_{m t}+\left.\partial_{t} C_{j}\right|_{s e d}+\left.\partial_{t} C_{j}\right|_{m p}-\left.\partial_{t} C_{j}\right|_{e v, s u},
$$

where $\left.\partial_{t} C_{j}\right|_{\text {sed }}$ is the rate due to transport together with sedimenting hydrometeors, and $\left.\partial_{t} C_{j}\right|_{m p}$ is the rate due to mass transfer between different hydrometeor categories.

The uptake and release of trace gases are assumed to be limited by the mass transfer across the interface of the hydrometeors and by the diffusion of the trace gas in the air surrounding the hydrometeors and is parameterized using firstorder rate coefficients (Schwartz, 1986). The rate of change of the aqueous phase concentration for hydrometeor category $j$ is

$$
\left.\partial_{t} C_{j}\right|_{m t}=f_{j} k_{j} L_{j} C_{g}-\frac{f_{j} k_{j}}{K_{H} R T} C_{j},
$$

where $f_{j}$ is the ventilation coefficient (Pruppacher and Klett, 1997), $L_{j}$ is the liquid water volume fraction of hydrometeors of category $j, K_{H}$ is the (temperature dependent) Henry's Law coefficient (see Table 2, $T$ is the temperature, and $R$ the universal gas constant, and $k_{j}$ is the first order rate coefficient (see e.g. Schwartz, 1986; Barth et al., 2001). Following Barth et al. (2001), the sedimentation rate is calculated using 


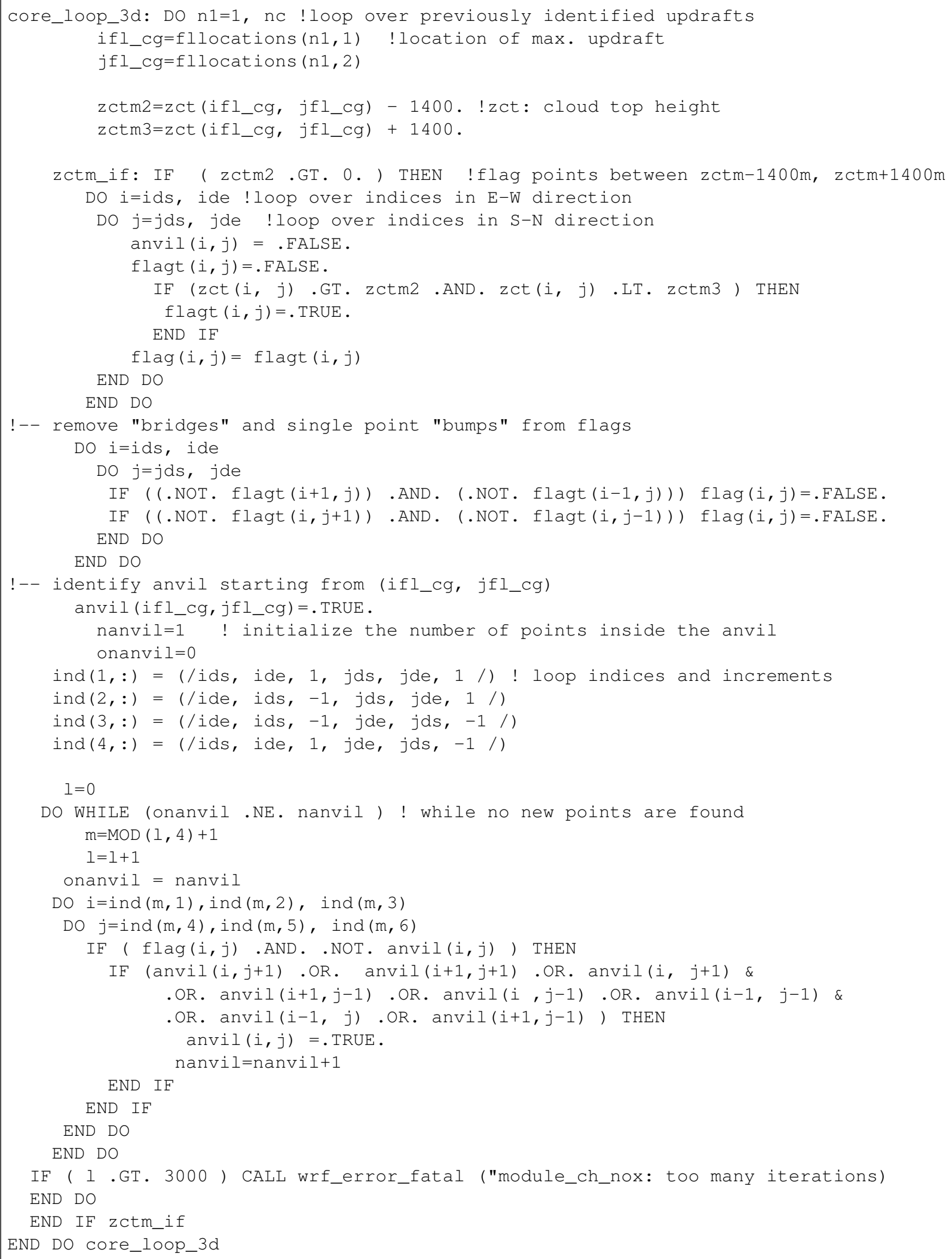

Code Excerpt 1: Simple method for flagging points inside an anvil in a multi-storm simulation. 
Table 2. Henry's Law Coefficients $H$

\begin{tabular}{lccc}
\hline & $\begin{array}{c}H_{298 K} \\
\left(\mathrm{~mol} \mathrm{l}^{-1} \mathrm{~atm}^{-1}\right)\end{array}$ & $\begin{array}{c}\Delta H / R \\
(\mathrm{~K})\end{array}$ & Reference \\
\hline $\mathrm{HNO}_{3}{ }^{(1,2)}$ & $2.1 \cdot 10^{5}$ & 8700 & Schwartz and White (1981) \\
$\mathrm{H}_{2} \mathrm{O}_{2}$ & $7.4 \cdot 10^{4}$ & 6615 & Lind and Kok (1986) \\
$\mathrm{HCHO}^{(3)}$ & $3.2 \cdot 10^{3}$ & 6800 & Staudinger and Roberts (1996) \\
$\mathrm{CH}_{3} \mathrm{OOH}$ & $3.1 \cdot 10^{2}$ & 5200 & O'Sullivan et al. (1996) \\
$\mathrm{CH}_{3} \mathrm{OH}$ & $2.2 \cdot 10^{2}$ & 5200 & Snider and Dawson (1985) \\
\hline${ }^{(1)}$ Temperature dependence: $H(T)=H_{298 K} e^{-\Delta H / R(1 / T-1 / 298)}$ \\
${ }^{(2)}$ For $\mathrm{HNO}_{3}$ the effective Henry's Law constant $H^{\text {eff }}=H\left(1+K_{A} /\left[H^{+}\right]\right)$ \\
where $K_{A}=15.1$ (Wurzler, 1995) is used for $\left[H^{+}\right]=10^{-5}(\mathrm{pH}=5)$. \\
(3) Diol formation is included.
\end{tabular}

the mass weighted mean terminal velocity $\bar{u}_{\infty j}$ (positive downward) of the falling hydrometeors (all except cloud droplets, where sedimentation is neglected):

$$
\left.\partial_{t} C_{j}\right|_{\text {sed }}=\partial_{z}\left(\bar{u}_{\infty j} C_{j}\right)
$$

The mass transfer between different hydrometeor categories is assumed to be proportional to the mass transfer of liquid or frozen water between the different categories as calculated by the microphysics parameterization:

$$
\left.\partial_{t} C_{j}\right|_{m p}=\sum_{k=1}^{5}\left(k_{\mathrm{ret}_{\mathrm{k}, \mathrm{j}}} R_{k, j} \frac{C_{k}}{q_{k}}-k_{\mathrm{ret}_{\mathrm{j}, \mathrm{k}}} R_{j, k} \frac{C_{j}}{q_{j}}\right),
$$

where $R_{k, j}=\left.\partial_{t} q_{j}\right|_{k \rightarrow j}$ is the rate of liquid or frozen water transfer from hydrometeors of category $k$ to hydrometeors of category $j$ due to a microphysical process; $k_{\text {ret }}$ is a dimensionless retention fraction (see next section) and is one for all processes except freezing and riming. Currently, the retention coefficient in the CSRMC is assumed to be independent of whether wet or dry growth riming or homogeneous freezing occurs. Effects of the so-called quasi-liquid layer (e.g. Diehl et al., 1995) (of which the structure is still largely unknown) are not considered.

\subsection{Ice uptake}

A number of large uncertainties regarding ice uptake still exist in current cloud resolving models and a satisfactory framework for describing burial processes at the same time as reversible surface uptake in 3-D models with bulk microphysics is still lacking (see e.g. Salzmann et al., 2007, for a discussion of the latter point). Ice uptake from the aqueous phase takes place as a result of tracer retention in freezing hydrometeors (see previous section). For $\mathrm{HNO}_{3}$ the retention coefficient is set to 1 (e.g. Stuart and Jacobson, 2003) and for $\mathrm{H}_{2} \mathrm{O}_{2} k_{\text {ret }}=0.05$ is assumed (based on Snider and Huang, 1998) independent of the freezing process. For the other soluble trace gases listed in Table $2 k_{\text {ret }}$ is set to 0.02 . For $\mathrm{CH}_{3} \mathrm{OOH}$ and $\mathrm{HCHO}$ this assumption is identical to the assumptions by Mari et al. (2000).

Direct uptake from and release to the gas phase are currently taken into account for $\mathrm{HNO}_{3}$ and $\mathrm{H}_{2} \mathrm{O}_{2}$. A number of laboratory studies have shown that $\mathrm{HNO}_{3}$ is efficiently taken up by ice (e.g. Diehl et al., 1995; Zondlo et al., 1997; Abbatt, 1997; Hynes et al., 2002). An exception is the study by Hudson et al. (2002). Tabazadeh et al. (1999) extrapolated the results of Abbatt (1997) to atmospheric $\mathrm{HNO}_{3}$ concentrations. Assuming Langmuir (temperature dependent, reversible, monolayer) adsorption they calculated that in precipitating cirrus clouds only a small fraction of the gas phase $\mathrm{HNO}_{3}$ is adsorbed on ice, while in clouds with higher ice particle number densities and smaller radii and at cold temperatures this fraction is close to one. Recent in-situ studies (Kondo et al., 2003; Popp et al., 2004; Ziereis et al., 2004) also indicate that at temperatures above $\sim 200-220 \mathrm{~K}$ only a small fraction of $\mathrm{HNO}_{3}$ is taken up by cloud ice particles (and that Tabazadeh et al., 1999, might have even overestimated the factional surface coverage under some conditions). At lower temperatures the fractional ice surface coverage by $\mathrm{HNO}_{3}$ molecules increases significantly and uptake is more efficient. In particular, Popp et al. (2004) and Ziereis et al. (2004) found that in some cold cirrus environments with high surface areas, $\mathrm{HNO}_{3}$ was completely partitioned on or in ice. This result is qualitatively consistent with Langmuir theory. Meilinger et al. (1999), on the other hand, found, based on in-situ measurements that the uptake of $\mathrm{HNO}_{3}$ by ice was very inefficient even at $\sim 196 \mathrm{~K}$. All in all, the number of insitu measurements is still relatively small and at this point any conclusions drawn should still be considered somewhat preliminary.

The uptake of $\mathrm{H}_{2} \mathrm{O}_{2}$ was studied by Conklin et al. (1993) in a flow tube packed with $200 \mu \mathrm{m}$ ice-spheres. Subsequently Meier and Hendricks (2002) calculated adsorption free energies based on the results of Conklin et al. (1993) which were 
below the values for $\mathrm{HNO}_{3}$ used by Tabazadeh et al. (1999) but above the adsorption enthalpy reported by BartelsRausch et al. (2002) for $\mathrm{HNO}_{3}$ on crystalline ice. Because $\mathrm{HNO}_{3}$ was shown to be more readily adsorbed on ice than $\mathrm{H}_{2} \mathrm{O}_{2}$ (see e.g. Clegg and Abbatt, 2001), the estimate by Meier and Hendricks (2002) is not used here. Instead the same adsorption enthalpy is used for $\mathrm{H}_{2} \mathrm{O}_{2}$ as has been found for $\mathrm{HNO}_{3}$ (i.e. $\Delta H_{a d s}=-44 \mathrm{~kJ} \mathrm{~mol}^{-1}$ ) by Bartels-Rausch et al. (2002).

For the uptake on ice the same mass transfer limitations apply as for liquid hydrometeors. An equation similar to Eq. (9) has been derived assuming Langmuir adsorption with dissociation (see Sect. 1.6.1):

$$
\left.\partial_{t} C_{i, j}\right|_{m t}=f_{i, j} k_{i, j} L_{j}\left(C_{i, g}-\frac{1}{K_{L i} R T} \frac{\theta_{i, j}^{2}}{\left(1-\theta_{i, j}\right)^{2}}\right)
$$

where $K_{L i}$ is the equilibrium constant:

$$
K_{L i}=K_{L i}^{r e f} \sqrt{\frac{T_{r e f}}{T}} \exp \left(\frac{\Delta H_{a d s}}{R}\left(\frac{1}{T_{r e f}}-\frac{1}{T}\right)\right) .
$$

$f_{i, j}$ and $k_{i, j}$ are as in Eq. (9) and $L_{j}$ is the ice volume fraction of ice category $j$. The surface coverage is calculated from (see Tabazadeh et al., 1999):

$$
\theta_{i, j}=\frac{\beta}{s_{j} \alpha \sigma} R T C_{i, j}
$$

where $\alpha=0.27$ is the fraction of surface sites that are assumed to be available for adsorption, $\sigma=10^{15}$ is the surface site density and $s_{j}$ is the ice surface area density. $\beta=9.6565 \cdot 10^{18} T^{-1}$ is a conversion factor.

For cloud ice and snow, $s_{j}$ is parameterized using the empirical relationship from Heymsfield and McFarquhar (1996):

$$
s_{j}=2 \cdot 10^{-4} \mathrm{IWC}^{0.9}
$$

where IWC is the ice content in $\mathrm{g} \mathrm{m}^{-3}$. Graupel (discussed in detail below) is assumed to have the surface area density of spheres with radius $\bar{a}=2 / \lambda$, where $\lambda$ is the slope of the graupel size distribution.

Trace gases absorbed by hydrometeors are usually assumed to be well mixed inside the hydrometeors, either due to diffusion in small droplets or due to turbulent mixing in larger drops. Because the diffusion coefficient for gases in solid ice is a few orders of magnitude smaller than that in liquid water, trace gases could theoretically be 'buried' inside (larger) ice particles. Burial could e.g. occur during the collection of super-cooled droplets by ice phase hydrometeors with subsequent freezing (riming). During riming, latent heat is released and the surface temperature of the ice particle can be either above $0^{\circ} \mathrm{C}$ (wet growth riming) or below $0^{\circ} \mathrm{C}$ (dry growth riming). The chemical retention during dry growth riming has been investigated recently e.g. by Stuart and Jacobson (2004). In the CSRMC, currently the same gas dependent retention coefficients are applied in Eq. (11) for the wet and the dry process and for all other freezing processes.

Burial could be considered a special case of retention. Retention could also occur as a consequence of strong adsorption on ice surfaces. Clegg and Abbatt (2001) suggested that measured retention fractions of $\mathrm{H}_{2} \mathrm{O}_{2}$ may be low compared to those of strong acids $\left(\mathrm{HCl}, \mathrm{HNO}_{3}\right)$ because of weaker adsorption on the ice surface.

Burial would lead to concentration gradients inside the ice phase hydrometeors and prevent equilibration between concentrations inside the ice particle and the gas phase. In this case, the mass transfer between the gas and the liquid phase would be limited by diffusion inside the ice phase hydrometeors and Eq. (12) would not be applicable. If, on the other hand, diffusivities in ice were sufficiently large to allow equilibration, then trace gases could not be buried in ice. In this case the uptake of trace gases would depend on the mass of the ice and not the surface area. Based on the observations cited above, for cirrus particles, however, the fraction of $\mathrm{HNO}_{3}$ taken up by ice compared to $\mathrm{HNO}_{3}$ remaining in the gas phase appears to be determined by the surface area and not the ice mass.

The diffusion coefficient for $\mathrm{HNO}_{3}$ in ice is still a subject of debate: e.g. Dominé and Thibert $(1996,1998)$ estimate $D_{\text {ice, } \mathrm{HNO}_{3}}$ to be about $10^{-10} \mathrm{~cm}^{2} \mathrm{~s}^{-1}$, while Sommerfeld et al. (1998) estimates an upper limit of $10^{-12} \mathrm{~cm}^{2} \mathrm{~s}^{-1}$. Furthermore, the effects of surface diffusion along crystalline boundaries are thought to be important. For comparison: a typical value for the aqueous-phase diffusion coefficient in liquid water is $D_{a q}=10^{-5} \mathrm{~cm}^{2} \mathrm{~s}^{-1}$.

The solution of the diffusion equation for a spherical particle yields the following timescale (see e.g. Seinfeld and Pandis, 1998):

$$
\tau_{\text {diff }}=\frac{a^{2}}{\pi^{2} D_{\text {diff }}} .
$$

For a theoretical $10 \mu \mathrm{m}$ ice sphere with $D_{i c e, H N O_{3}}=$ $10^{-10} \mathrm{~cm}^{2} \mathrm{~s}^{-1}$ the time scale is $\tau_{\text {diff }} \approx 17 \mathrm{~min}$, which is long compared to typical time scales for uptake in liquid hydrometeors. Unfortunately, burial effects are not readily parameterized in cloud resolving models without neglecting surface exchange. In the present study, Eq. (12) was applied to calculate the uptake by and release from cloud ice and snow.

In the present study only the burial of $\mathrm{HNO}_{3}$ in graupel is parameterized by assuming quasi-irreversible uptake from the gas phase. This is achieved by allowing 100 monolayers of $\mathrm{HNO}_{3}$ to exist on graupel particles and can lead to an overestimation of $\mathrm{HNO}_{3}$ uptake from the gas phase. The assumption of spherical graupel particles, on the other hand, could lead to an underestimate of the uptake by graupel given the relatively low density of graupel in the model, which suggests non spherical graupel particles. 
Currently, in the CSRMC no distinction is being made between $\mathrm{HNO}_{3}$ enclosed in ice phase hydrometeors and $\mathrm{HNO}_{3}$ available at the surface. Furthermore, the uptake of $\mathrm{HNO}_{3}$ on cloud ice particles and on snow is treated as a reversible process, thus in principle allowing the release of $\mathrm{HNO}_{3}$ from the ice phase in spite of the retention coefficient being set to one. This is a problem which to the author's knowledge has not yet been solved in cloud resolving model studies. Yin et al. (2002), who studied the effect of the ice phase on convective transport in an axis-symmetric cloud model, assumed uptake on ice to be generally irreversible, in principle allowing ice to act as an infinite trace gas sink in the model. Barth et al. (2001) did not assume adsorption on ice in their CRM study of the effects of retention. One possible direction for future studies using bulk microphysics schemes to study trace gases which can be taken up by ice from the gas phase would be to include one variable for the amount of trace gas entrapped in ice and one variable for the amount of trace gas available for reversible exchange between gas and ice phase at the surface of the ice phase hydrometeors, i.e. to include two trace gas variables for each frozen hydrometeor category in the model (6 ice-phase related variables for each trace gas compound taken up by ice from the gas phase in the five-category single moment microphysics scheme). However, this approach would complicate the solution of the equation for the mass transfer between different hydrometeor categories due to cloud microphysical processes (Eq. (11)), and introduce substantial new uncertainties.

The effect of a quasi liquid layer on graupel (see e.g. Conklin et al., 1993; Diehl et al., 1995) as well as the effect of a combination of $\mathrm{HNO}_{3}$ molecules with $\mathrm{H}_{2} \mathrm{O}$ molecules to form NAT (nitric acid trihydrate, $\mathrm{HNO}_{3} \cdot 3 \mathrm{H}_{2} \mathrm{O}$ ) (see e.g. Tabazadeh and Turco, 1993; Meilinger et al., 1999; Gao et al., 2004) and the effect of possible multi-layer uptake at low temperatures (e.g. Hudson et al., 2002) are not investigated in the present study. Further studies regarding the role of the ice phase on deep convective chemistry transport are, however, currently being planned in the framework of a follow-up study.

\subsubsection{Derivation of Eq. (12)}

Eq. (12) can be derived from the following mass transfer equation (Schwartz, 1986; Pruppacher and Klett, 1997; Seinfeld and Pandis, 1998):

$$
\left.\partial_{t} C\right|_{m t}=f k L\left(C_{g}^{\infty}-C_{g}^{\text {surf }}\right),
$$

where $f$ is the ventilation coefficient, $k$ is the gas specific mass transfer coefficient (as in e.g. Schwartz, 1986) and $L$ is the liquid water or ice volume fraction. $C_{g}^{\infty}$ is the grid box average gas phase concentration of a trace gas and $C_{g}^{\text {surf }}$ is the gas phase concentration of tracer $i$ near the surface of the hydrometeors in the liquid or ice phase. Eq. (17) was derived solving the diffusion equation assuming spherical symmetry. For snow and cloud ice in the CSRMC, spherical symmetry is only assumed for the gas phase diffusion towards the meteor, while the surface area is parameterized using Eq. (15). In deriving Eq. (9), which describes the mass transfer between liquid hydrometeors and the gas phase, Henry's Law is used in Eq. (17) to calculate $C_{g}^{\text {surf }}$. Instead of using a so-called “quasi Henry's Law" for ice phase hydrometeors (e.g. Conklin et al., 1993), $C_{g}^{\text {surf }}$ is calculated assuming dissociative Langmuir adsorption (e.g. Laidler et al., 1940; Adamson and Gast, 1997):

$$
P_{\text {surf }}=\frac{1}{K_{L}} \frac{\theta^{2}}{(1-\theta)^{2}}
$$

Using the ideal gas law $P_{\text {surf }}=R T C_{g}^{\text {surf }}$, where $\mathrm{R}$ is the universal gas constant:

$$
C_{g}^{\text {surf }}=\frac{1}{K_{L} R T} \frac{\theta^{2}}{(1-\theta)^{2}} .
$$

Equation (12) follows from inserting Eq. (19) into Eq. (17). A Rosenbrock type solver is applied in order to numerically solve Eq. (12). The variables in the equation are scaled so that the solver returns a positive numerical solution which convergences towards Langmuir equilibrium.

\section{Chemical initial and boundary conditions}

The chemical initial and lateral boundary conditions (see also Sect. 8) for the CSRMC runs are derived from global chemistry-transport simulations with MATCH-MPIC (Model of Atmospheric Transport and Chemistry - Max Planck Institute for Chemistry). MATCH-MPIC output has been archived after every two hours of simulated time and the lateral trace gas boundary conditions for the CSRMC are derived by linearly interpolating output data from a model column centered at $1.4^{\circ} \mathrm{S}, 157.5^{\circ} \mathrm{E}$ close to the center of the TOGA COARE IFA (Fig. 2). The stratospheric concentrations of methane and of $\mathrm{NO}_{\mathrm{y}}\left(=\mathrm{NO}+\mathrm{NO}_{2}+\mathrm{NO}_{3}+\mathrm{HNO}_{3}\right)$ above $17.5 \mathrm{~km}$ are specified based on output from MATCHMPIC which was constrained by observations as described by von Kuhlmann et al. (2003a); i.e. the model calculated concentrations of the members of the $\mathrm{NO}_{\mathrm{y}}$ group are scaled in order for the concentration of $\mathrm{NO}_{\mathrm{y}}$ to remain constant and the partitioning between the concentrations of the different members calculated by the model is not changed.

\section{Meteorological conditions and evaluation}

A seven day episode from 19-26 December 1992 at the site of the TOGA COARE (Webster and Lukas, 1992) Intensive Flux Array (IFA, centered at $2^{\circ} \mathrm{S}, 156^{\circ} \mathrm{E}$ ) is simulated which overlaps with the episode chosen by the GEWEX Cloud System Study (GCSS Science Team, 1993) Working Group 4 as 


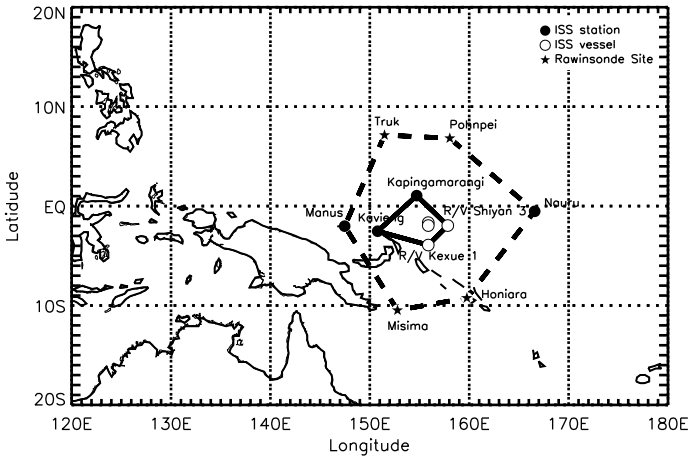

Fig. 2. Sounding sites in the TOGA COARE region. Solid line: Intensive Flux Array (IFA), dotted line: Outer Sounding Array (OSA).
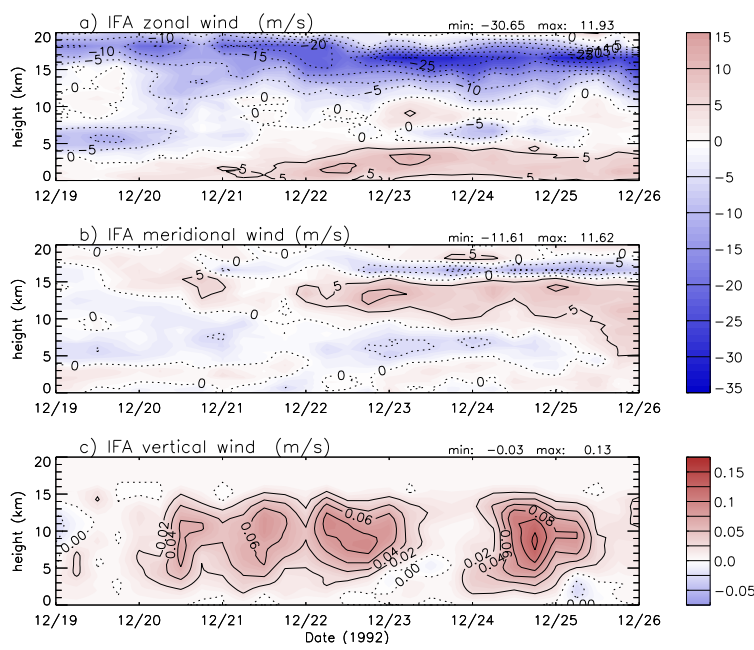

Fig. 3. Time-height contour plots of large scale (a) zonal (b) meridional and (c) vertical wind components. Data from Ciesielski et al. (2003).

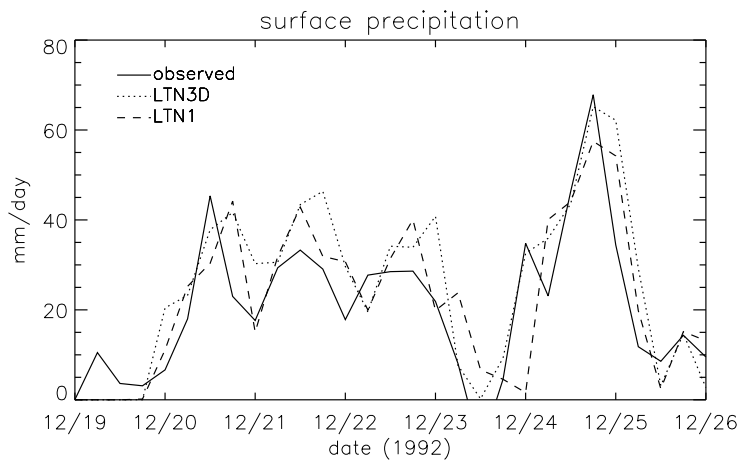

Fig. 4. Observed and simulated $6 \mathrm{~h}$ averaged surface precipitation rates for the LTN3D run and the 2-D lightning sensitivity runs. the second case of their first cloud-resolving model intercomparison project (Krueger and Lazarus, 1999) and was also investigated by Wu et al. (1998), Andronache et al. (1999), Su et al. (1999), Johnson et al. (2002), Salzmann et al. (2004), and used in a model comparison by Gregory and Guichard (2002). During this period the IFA region is influenced by the onset of a westerly wind burst (Fig. 3a) and three consecutive convection maxima develop between 20 and 23 December and a fourth and strongest maximum with its peak on 24 December at the times of maximum large-scale ascent (Fig. 3c).

The precipitation rates in the CSRMC runs generally compare well with the observation derived rates (Fig. 4) and a number of larger mesoscale convective systems (MCS) develop in addition to some more isolated deep convection in the LTN3D run (Fig. 5). The total observed amount of rain for the seven day period from 19-26 December 1992 is calculated from the Ciesielski et al. (2003) data to be $149.1 \mathrm{~mm}$. The simulated amount is $162.6 \mathrm{~mm}$ in the 2-D runs (as in Salzmann et al., 2004) and $184.0 \mathrm{~mm}$ in the 3-D run which is more than the $171.8 \mathrm{~mm}$ we calculated in a 3-D run with a higher vertical resolution (Salzmann et al., 2004). The temperature and water vapor biases (Fig. 6) are comparable in magnitude and shape to Salzmann et al. (2004) and the hydrometeor mixing ratios in Fig. 7 are similar to Salzmann et al. (2007).

\section{Lightning $\mathrm{NO}_{\mathrm{x}}$ and reactive nitrogen compounds}

\subsection{Flash rates}

Lucas and Orville (1996) analyzed cloud to ground (CG) lightning observations from the advanced lightning direction finder (ALDF) network operated in the TOGA COARE region for January and February 1993. They found very variable daily flash counts and suggested the lightning frequency in the TOGA COARE region to be modulated by the intra-seasonal oscillation. The highest CG flash counts were detected between 11 and 17 February during a westerly phase of the intra-seasonal oscillation. During this period daily flash counts slightly exceeded 5000 for their oceanic sector spanning roughly 2.6 million square kilometers. Petersen et al. (1996) reported flash counts for 31 January to 26 February 1993 performed from aboard the research vessel "Vickers" which was located within the region of the TOGA COARE IFA. For 10 and 11 February, more than $800 \mathrm{CG}$ flashes daily were counted over a $600 \mathrm{~km} \times 600 \mathrm{~km}$ area (see their Fig. 10). From this, the daily area flash density can be roughly estimated to equal $0.0022 \mathrm{CG}$ flashes per $\mathrm{km}^{2}$ per day on days with high lightning activity during seasons (Orville et al., 1997) with high lightning activity.

The number of CG flashes in our LTN3D run is 1021 (Table M1) and the average area flash density during the last 6 days of the simulation (after the onset of deep convection 


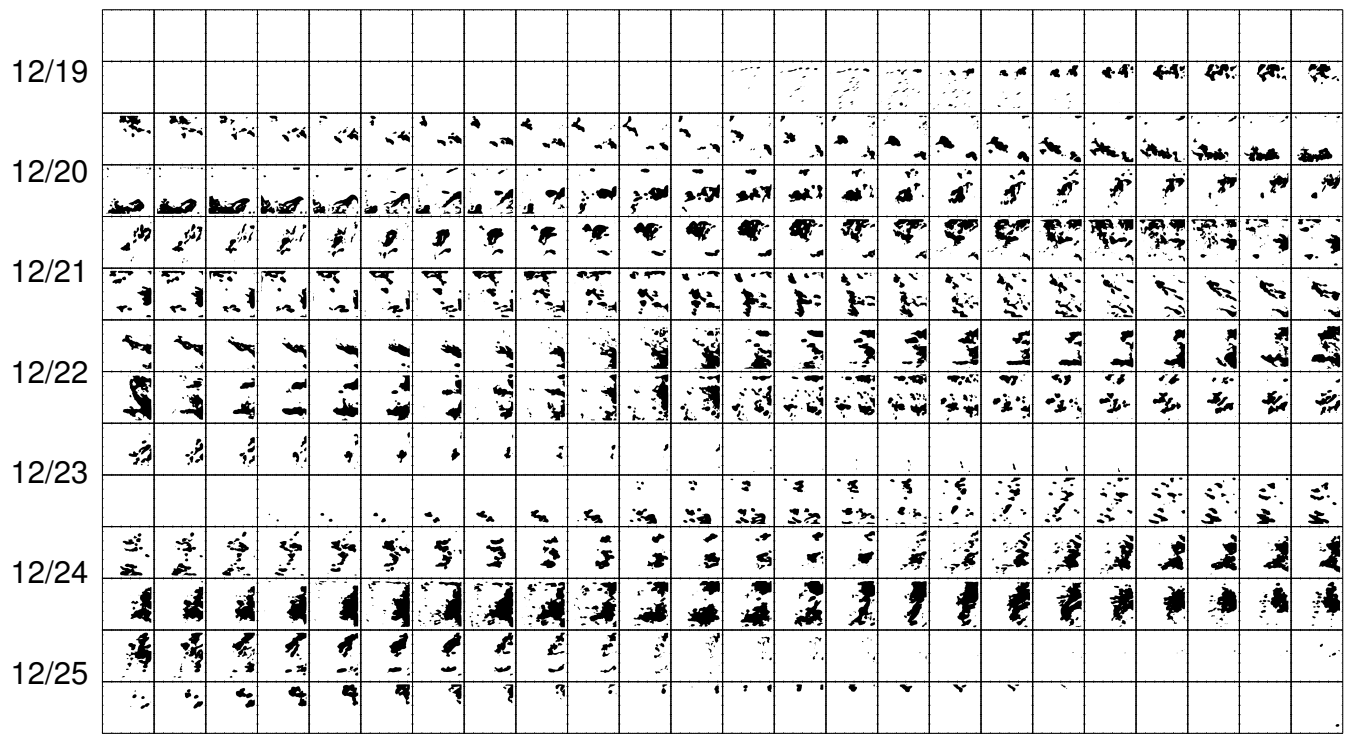

Fig. 5. Series of $\mathrm{X}-\mathrm{Y}$ contour plots with $1 \mathrm{~mm} \mathrm{~h}^{-1}$ filled contour of simulated rainfall rates for the LTN3D run. The X-axes are directed in $\mathrm{W}-\mathrm{E}$ direction and the Y-axes in S-N direction. The interval between the individual plots is 30 min, i.e. each row represents one half day.
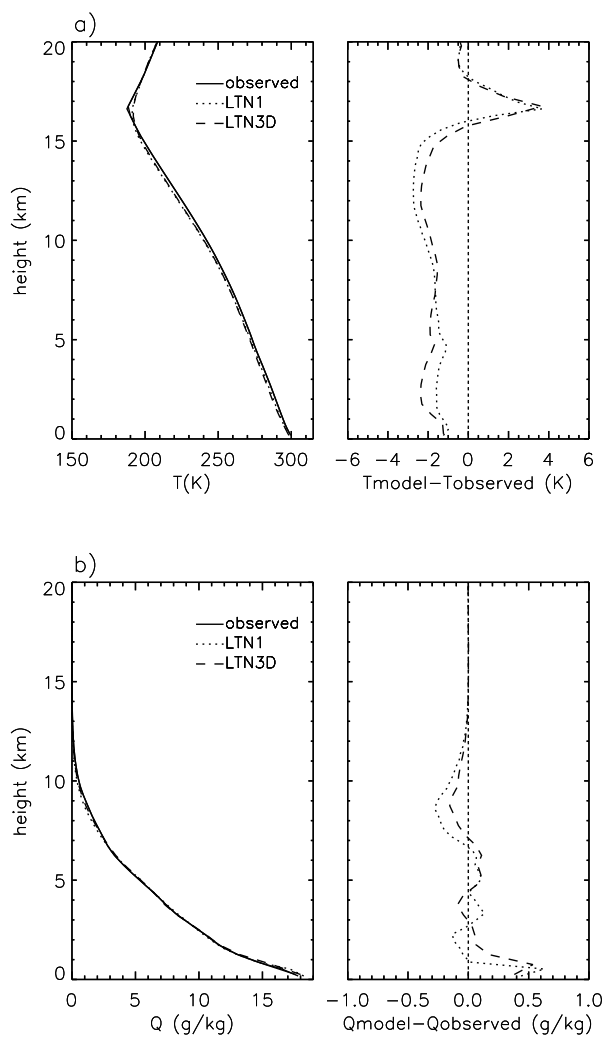

Fig. 6. Vertical profiles of simulated and observed average temperatures and water vapor mixing ratios.
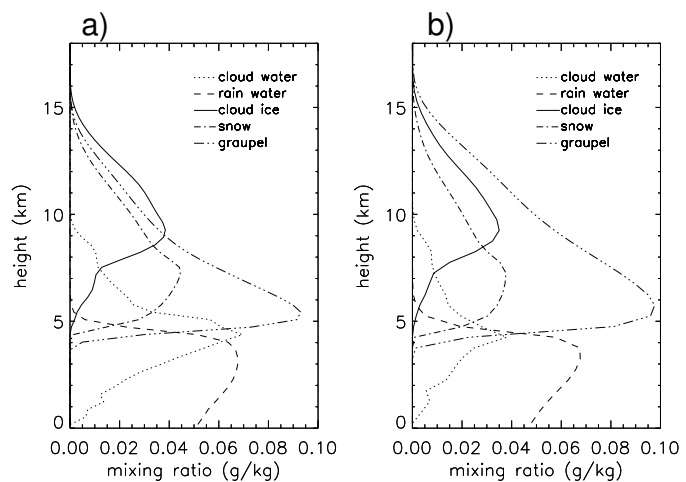

Fig. 7. Averages of simulated hydrometeor mass mixing ratios for (a) the 2-D runs and (b) the LTN3D run.

in the model) is $0.0028 \mathrm{CG}$ flashes per $\mathrm{km}^{2}$ per day, which agrees with the observations within $\sim 30 \%$. Unfortunately, the number of IC flashes has not been observed by the ALDF and also the airborne observations are not sufficient to determine the ratio of IC to CG flashes or the total number of flashes. Furthermore, the fraction of IC flashes erroneously recorded as CG flashes by the ALDF network is uncertain (see Lucas and Orville, 1996; Petersen et al., 1996), so that ALDF derived area densities of CG flashes might have to be considered an upper limit.

In the LTN3D run, $Z=10.43$, and in the LTN1 run $Z=$ 8.21 (Table M1) which is in line with Pierce (1970) (Table 3). In the other lightning sensitivity runs, $z$ is prescribed to be 2.76 as in Wang and Prinn (2000). 
Table 3. Ratio $Z=$ (number of IC flashes)/(number of CG flashes) from selected studies.

\begin{tabular}{cc}
\hline$Z$ & Reference \\
$\sim 9$ (equator) to $\sim 0.67\left(65^{\circ}\right.$ latitude) & Pierce (1970) \\
$\sim 6$ (equator) to $\sim 2\left(60^{\circ}\right.$ latitude) & Prentice and Mackerras (1977) \\
$3.0(0.9-24.7)$ Brisbane, Australia & Mackerras (1985) \\
$\sim 3.2$ (equator) to $\sim 2.7\left(40^{\circ} \text { latitude }\right)^{1}$ & Price and Rind (1993) \\
1.7 to 3.5 globally & Price et al. (1997) \\
3.6 to 5.5 globally & Mackerras et al. (1998) \\
$7.3(2.6-16.1)$ Darwin, Australia & Rutledge et al. (1992) \\
\hline
\end{tabular}

${ }^{1}$ estimated from Fig. 4b of Price and Rind (1993).

2 estimated from Fig. 7 of Rutledge et al. (1992).

4.2 Comparison of modeled $\mathrm{NO}$ and $\mathrm{NO}_{\mathrm{x}}$ with observations

Table 4 shows that the low upper tropospheric $\mathrm{NO}_{\mathrm{x}}$ volume mixing ratios in the LTN3D run are similar to those observed during the "low $\mathrm{NO}_{\mathrm{x}}$ regime" by Crawford et al. (1997). This regime has been suggested to be predominantly influenced by marine deep convection, while elevated upper tropospheric $\mathrm{NO}_{\mathrm{x}}$ volume mixing ratios in the "high $\mathrm{NO}_{\mathrm{x}}$ regime" have been attributed to lightning over New Guinea and subsequent transport.

\subsection{Details of the $\mathrm{NO}_{\mathbf{x}}$ budget}

Figs. 8 and 9 show time resolved average $\mathrm{NO}_{\mathrm{x}}$ volume mixing ratios and budget terms for the LTN3D and the LTN1 run, respectively. The time integrated budget is discussed in Sect. M3.3. The maximum chemical $\mathrm{NO}_{\mathrm{x}}$ losses in the LTN1 run are calculated to occur during daytime (Fig. 9g). In the LTNHWP run, on the other hand, high nighttime losses are also calculated to occur (not shown).

Average $\mathrm{NO}_{\mathrm{x}}$ column densities and tendency terms are shown in Table 5. Again, only the last six days of the model runs are taken into account while the first day is omitted because deep convection in the model did not set in until the end of this day. The troposphere is divided into lower troposphere (LT), mid-troposphere (MT), and upper troposphere (UT), reaching from the surface to $\sim 5 \mathrm{~km}$, from $\sim 5$ to $\sim 10 \mathrm{~km}$, and from $\sim 10$ to $\sim 16 \mathrm{~km}$ altitude, respectively. The tropospheric column (TC) is defined from the surface to $\sim 16 \mathrm{~km}$. For the tropospheric column, non-zero vertical advection terms can loosely be interpreted as caused by exchange between the troposphere (as defined by the tropospheric column from the surface to $\sim 16 \mathrm{~km}$ ) and the stratosphere. The vertical advection terms integrated over the tropospheric column are negative and small compared to the other terms for all lightning sensitivity runs, which can be interpreted as a small net trans-
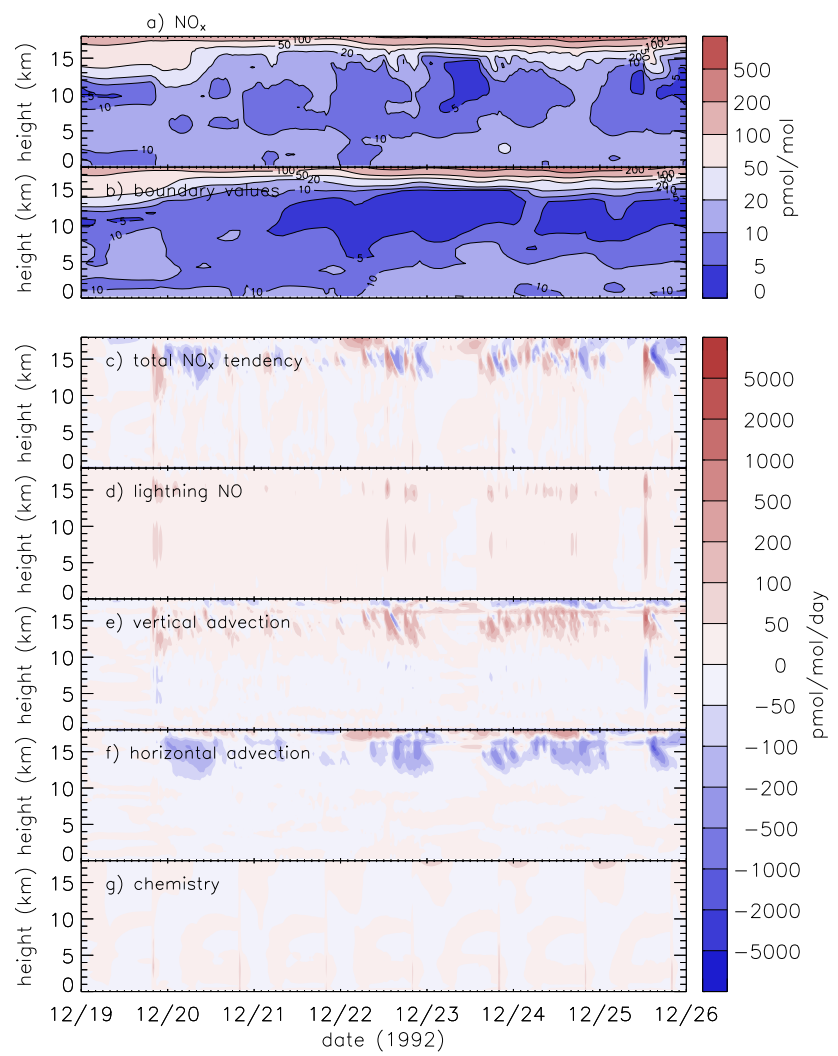

Fig. 8. (a) Time series of domain-averaged $\mathrm{NO}_{\mathrm{x}}$ volume mixing ratios for the LTN3D run. (b) Boundary values. (c)-(g) budget terms as defined by Eq. (M4). 
Table 4. $\mathrm{NO}$ and $\mathrm{NO}_{\mathrm{x}}$ volume mixing ratios from studies using observations and from the LTN3D and the LTN1 run.

\begin{tabular}{|c|c|c|c|}
\hline Reference & height $(\mathrm{km})$ & $\mathrm{NO}\left(\mathrm{pmol} \mathrm{mol}{ }^{-1}\right)$ & $\mathrm{NO}_{\mathrm{x}}\left(\mathrm{pmol} \mathrm{mol}{ }^{-1}\right)$ \\
\hline Crawford et al. (1997) ${ }^{1}$ & & median $^{2}$ & median $^{2}$ \\
\hline \multirow{6}{*}{ low $\mathrm{NO}_{\mathrm{x}}$} & $0-1$ & 5.0 & 19.2 \\
\hline & $1-2$ & 5.8 & 19.1 \\
\hline & $2-4$ & 4.2 & 11.8 \\
\hline & $4-6$ & 5.6 & 9.5 \\
\hline & $6-8$ & 5.3 & 8.0 \\
\hline & $8-10$ & 6.8 & 6.8 \\
\hline \multirow[t]{6}{*}{ high $\mathrm{NO}_{\mathrm{x}}$} & $0-1$ & 6.9 & 29.1 \\
\hline & $1-2$ & 6.1 & 24.1 \\
\hline & $2-4$ & 11.1 & 32.0 \\
\hline & $4-6$ & 18.9 & 41.6 \\
\hline & $6-8$ & 30.0 & 48.1 \\
\hline & $8-10$ & 60.7 & 69.0 \\
\hline Kondo et al. $(1996)^{3}$ & & median $^{4}$ & median $^{4}$ \\
\hline \multirow[t]{4}{*}{ marine/tropical } & $0-1$ & 2.3 & 6.6 \\
\hline & $1-4$ & 3.3 & 9.6 \\
\hline & $4-7$ & 7.3 & 12.5 \\
\hline & $7-12$ & 12.4 & 16.4 \\
\hline maritime western & $0-1$ & 3.7 & 12.5 \\
\hline \multirow[t]{3}{*}{ Pacific } & $1-4$ & 5.1 & 13.8 \\
\hline & $4-7$ & 11.5 & 19.4 \\
\hline & $7-12$ & 26.6 & 36.4 \\
\hline Kondo et al. (1997) ${ }^{5}$ & & median $^{4}$ & median $^{4}$ \\
\hline \multirow[t]{4}{*}{ marine/tropical } & $0-1$ & 4.6 & 44.2 \\
\hline & $1-4$ & 3.3 & 14.4 \\
\hline & $4-7$ & 7.3 & - \\
\hline & $7-12$ & 59.9 & 84.2 \\
\hline this study & & median $^{6}$ & median $^{6}$ \\
\hline \multirow[t]{6}{*}{ LTN3D } & $0-2$ & 3.2 & 10.7 \\
\hline & $2-4$ & 4.8 & 13.6 \\
\hline & $4-6$ & 4.2 & 10.0 \\
\hline & $6-8$ & 4.0 & 7.4 \\
\hline & $8-10$ & 4.7 & 6.7 \\
\hline & $10-14$ & 7.0 & 8.2 \\
\hline this study & & median $^{6}$ & median $^{6}$ \\
\hline \multirow[t]{6}{*}{ LTN1 } & $0-2$ & 3.5 & 12.2 \\
\hline & $2-4$ & 5.6 & 16.2 \\
\hline & $4-6$ & 6.2 & 14.5 \\
\hline & $6-8$ & 7.6 & 13.9 \\
\hline & $8-10$ & 13.0 & 17.9 \\
\hline & $10-14$ & 17.2 & 19.6 \\
\hline
\end{tabular}

${ }^{1}$ Analysis for the "remote tropical component" of PEM-West B, i.e. most flights northwest of the TOGA COARE region (latitudes ranged from about $10^{\circ} \mathrm{S}$ to $30^{\circ} \mathrm{N}$ and flights along the Pacific rim have been excluded). The values in the table have been estimated based on Figs. 3 and 4 of Crawford et al. (1997).

${ }^{2}$ For $\mathrm{SZA}<60^{\circ}$.

${ }^{3}$ Air mass classification based on back trajectory calculations for PEM-West A .

${ }^{4}$ For $\mathrm{SZA}<70^{\circ}$.

${ }^{5}$ Same classification as Kondo et al. (1996) for PEM-West B.

${ }^{6}$ Vertically averaged median mixing ratios for $\mathrm{SZA}<70^{\circ}$ from Fig. M5. 


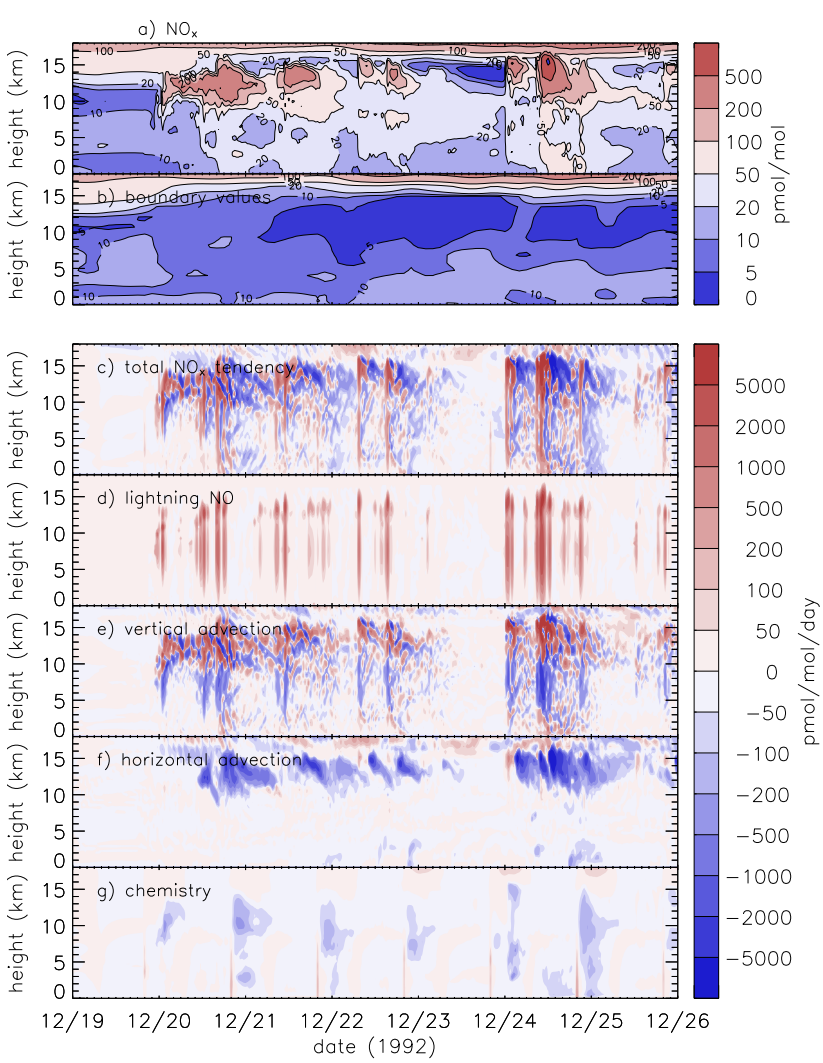

Fig. 9. Same as Fig. 8 for the LTN1 run.
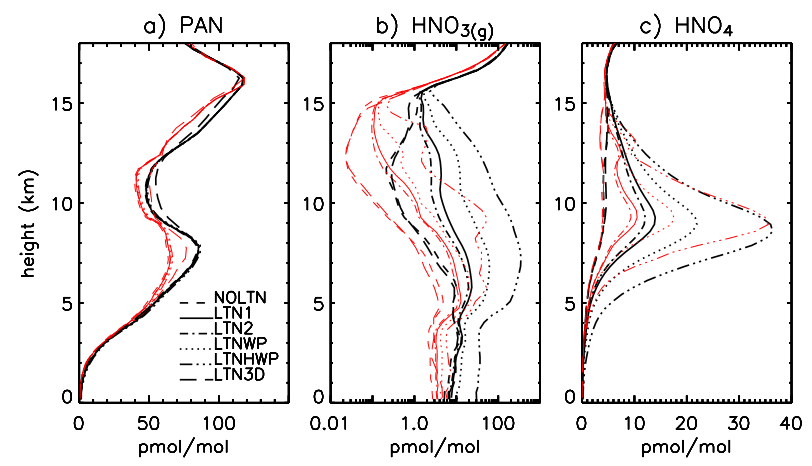

Fig. 10. Average (black) and median (red) volume mixing ratios of (a) PAN, (b) gas phase $\mathrm{HNO}_{3}$, and (c) $\mathrm{HNO}_{4}$ for $\mathrm{SZA}<70^{\circ}$.

port out of the troposphere. A discussion of exchange between stratosphere and troposphere, taking into account the complexity of the model setup including VLSAT terms, is found in Sect. 5.3.

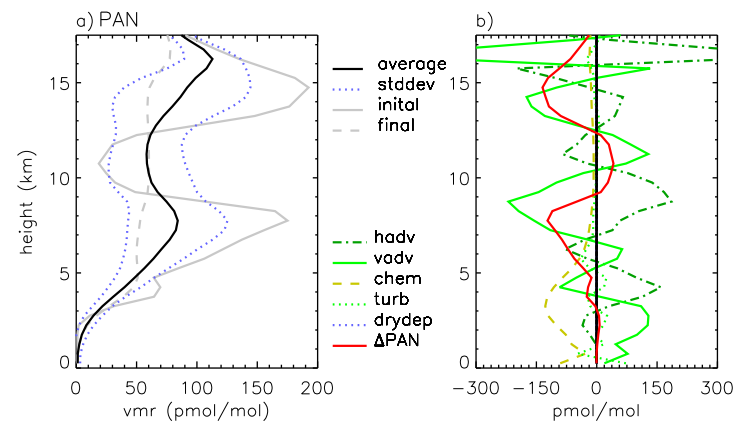

Fig. 11. (a) Time and domain-averaged PAN volume mixing ratio, averaged PAN volume mixing ratio \pm standard deviation, initial, and final PAN volume mixing ratio profiles for the LTN3D run. (b) Budget terms (from Eq. (M4), divided by the average air density) and the difference between the initial and the final profile (red line) for the LTN3D run.

\subsection{Other reactive nitrogen compounds}

\subsubsection{Peroxyacetyl Nitrate (PAN)}

PAN is thermally unstable: at high temperatures it decomposes rapidly to form $\mathrm{NO}_{2}$ and the peroxyacetyl radical $\left(\mathrm{CH}_{3} \mathrm{C}(\mathrm{O}) \mathrm{O}_{2}\right)$ through $\mathrm{R} 59$ (see Table 1). Its lifetime increases with height from a few hours at warm surface air temperatures to about a month in the upper troposphere. Large net PAN formation generally takes place close to the continental sources of precursor gases; i.e. in regions with high concentrations of non-methane hydrocarbons (NMHCs Singh and Hanst, 1981; Kasting and Singh, 1986). Here, the focus is on processes leading to a net loss of PAN, and only acetone is considered as a direct precursor (R61). The volume mixing ratios in Fig. 10a are somewhat higher than observations in maritime tropical air presented by Kondo et al. (1997), but still significantly lower than those found in air of continental origin by Kondo et al. (1997). PAN is generally over-predicted by MATCH-MPIC (von Kuhlmann et al., 2003b) resulting in elevated boundary values for the CSRMC, and consequently elevated volume mixing ratios inside the domain. The domain integrated volume mixing ratios in Fig. 10 are largely insensitive to the changes in lightning $\mathrm{NO}_{\mathrm{x}}$ production and the associated changes in $\mathrm{OH}$ concentrations (discussed in Sect. M5). Height dependent budget terms for PAN from the LTN3D run are shown in Fig 11b. In the upper and mid-troposphere, horizontal advection is an important source of PAN, from where it is on average transported downwards. The maximum net chemical loss takes place around $3 \mathrm{~km}$. Close to the surface, the lifetime is too short for large horizontal transport to occur. 
Table 5. $\mathrm{NO}_{\mathrm{x}}$ column densities and height integrated $\mathrm{NO}_{\mathrm{x}}$ budget terms as defined by Eq. (M5) for the last six days of the lightning sensitivity runs.

\begin{tabular}{|c|c|c|c|c|}
\hline & $\mathrm{LT}^{\mathrm{a}}$ & $\mathrm{MT}^{\mathrm{b}}$ & $\mathrm{UT}^{\mathrm{c}}$ & $\mathrm{TC}^{\mathrm{d}}$ \\
\hline \multicolumn{5}{|c|}{ LTN3D } \\
\hline av. column density ${ }^{1}$ & 1.21 & 0.50 & 0.53 & 2.23 \\
\hline lightning $\mathrm{NO}^{2}$ & 0.35 & 0.73 & 0.44 & 1.52 \\
\hline vertical advection ${ }^{2}$ & -0.37 & -0.56 & 0.90 & -0.03 \\
\hline horizontal advection ${ }^{2}$ & -0.17 & -0.10 & -1.49 & -1.77 \\
\hline chemistry $^{2}$ & 0.20 & -0.13 & -0.09 & -0.01 \\
\hline turbulence param. ${ }^{2}$ & -0.02 & 0.01 & 0.01 & 0.01 \\
\hline total tendency ${ }^{2,3}$ & -0.03 & -0.05 & -0.23 & -0.31 \\
\hline \multicolumn{5}{|c|}{ NOLTN } \\
\hline av. column density ${ }^{1}$ & 1.27 & 0.55 & 0.42 & 2.25 \\
\hline vertical advection ${ }^{2}$ & -0.12 & 0.05 & 0.04 & -0.03 \\
\hline horizontal advection ${ }^{2}$ & -0.18 & -0.04 & -0.19 & -0.42 \\
\hline chemistry $^{2}$ & 0.37 & -0.04 & 0.00 & 0.34 \\
\hline turbulence param. ${ }^{2}$ & -0.02 & 0.02 & 0.01 & 0.01 \\
\hline total tendency ${ }^{2,3}$ & 0.05 & -0.01 & -0.15 & -0.11 \\
\hline \multicolumn{5}{|c|}{ LTN1 } \\
\hline av. column density ${ }^{1}$ & 2.19 & 2.04 & 3.42 & 7.65 \\
\hline lightning $\mathrm{NO}^{2}$ & 2.67 & 7.65 & 4.50 & 14.82 \\
\hline vertical advection $^{2}$ & -0.43 & -5.98 & 6.38 & -0.04 \\
\hline horizontal advection ${ }^{2}$ & -1.13 & -0.28 & -10.08 & -11.48 \\
\hline chemistry $^{2}$ & -0.95 & -1.30 & -0.76 & -3.01 \\
\hline turbulence param. ${ }^{2}$ & -0.05 & 0.04 & -0.04 & -0.05 \\
\hline total tendency ${ }^{2,3}$ & 0.09 & 0.11 & 0.02 & 0.22 \\
\hline \multicolumn{5}{|c|}{ LTN2 } \\
\hline av. column density ${ }^{1}$ & 1.96 & 1.66 & 2.40 & 6.02 \\
\hline lightning $\mathrm{NO}^{2}$ & 1.98 & 5.47 & 2.51 & 9.95 \\
\hline vertical advection $^{2}$ & -0.37 & -4.27 & 4.57 & -0.07 \\
\hline horizontal advection ${ }^{2}$ & -0.90 & -0.22 & -6.56 & -7.67 \\
\hline chemistry $^{2}$ & -0.58 & -0.94 & -0.53 & -2.05 \\
\hline turbulence param. ${ }^{2}$ & -0.04 & 0.03 & -0.02 & -0.03 \\
\hline total tendency ${ }^{2,3}$ & 0.08 & 0.06 & 0.03 & 0.11 \\
\hline \multicolumn{5}{|c|}{ LTNWP } \\
\hline av. column density ${ }^{1}$ & 3.56 & 4.15 & 7.70 & 15.41 \\
\hline lightning $\mathrm{NO}^{2}$ & 8.37 & 22.04 & 5.86 & 36.27 \\
\hline vertical advection $^{2}$ & -2.08 & -17.80 & 20.05 & 0.17 \\
\hline horizontal advection ${ }^{2}$ & -2.57 & -0.56 & -23.83 & -26.96 \\
\hline chemistry $^{2}$ & -3.38 & -3.56 & -1.67 & -8.60 \\
\hline turbulence param. ${ }^{2}$ & -0.13 & 0.06 & -0.07 & -0.13 \\
\hline total tendency ${ }^{2,3}$ & 0.16 & 0.14 & 0.33 & 0.64 \\
\hline
\end{tabular}

${ }^{\text {a }}$ Lower troposphere (LT) defined from the surface to $\sim 5 \mathrm{~km}$ height.

${ }^{\mathrm{b}}$ Mid troposphere (MT), from $\sim 5 \mathrm{~km}$ to $\sim 10 \mathrm{~km}$.

${ }^{\mathrm{c}}$ Upper troposphere (UT), from $\sim 10 \mathrm{~km}$ to $\sim 16 \mathrm{~km}$.

d Tropospheric column (TC), from the surface to $\sim 16 \mathrm{~km}$.

${ }^{1}$ Expressed in $10^{14}$ molecules $\mathrm{cm}^{-2}$. (The tropospheric air column density is $\sim 1.9 \cdot 10^{25}$ molecules $\mathrm{cm}^{-2}$.)

${ }^{2}$ In $10^{14}$ molecules $\mathrm{cm}^{-2}$ day $^{-1}$.

${ }^{3}$ Diagnosed from the change of column density. 


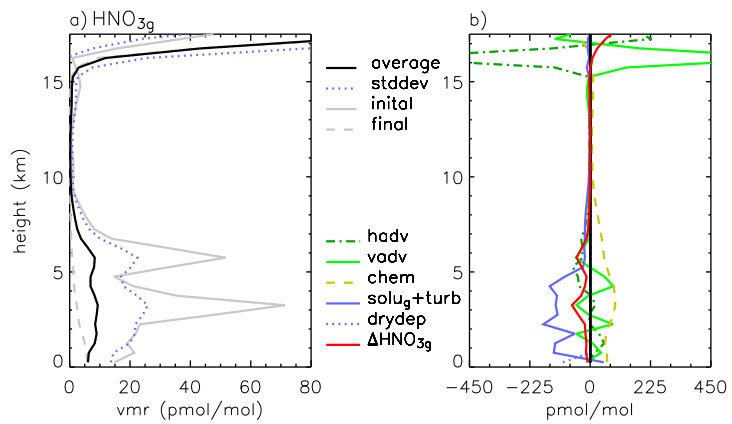

Fig. 12. As Fig. 11 for $\mathrm{HNO}_{3}$.

\subsubsection{Nitric Acid $\left(\mathrm{HNO}_{3}\right)$}

The reaction of $\mathrm{NO}_{2}$ with $\mathrm{OH}$ to form $\mathrm{HNO}_{3}$ (R29) and subsequent scavenging of $\mathrm{HNO}_{3}$ is a major sink of $\mathrm{NO}_{\mathrm{x}}$ in the troposphere. While PAN is generally over-predicted in MATCH-MPIC, $\mathrm{HNO}_{3}$ is often underestimated (von Kuhlmann et al., 2003b). Due to the low initial and boundary values, the CSRMC calculated $\mathrm{HNO}_{3}$ volume mixing ratios in Fig. 10b are also low compared to observations presented by Kondo et al. (1997), independent of assumptions regarding lightning (except for the LTNHWP run). Because of the time it takes to form $\mathrm{HNO}_{3}$ from $\mathrm{NO}_{2}$ and $\mathrm{OH}$, Chameides et al. (1987) argued that one would not expect $\mathrm{NO}$ production by lightning to result in immediate nitrate $\left(\mathrm{NO}_{3}^{-}\right)$enhancements in the rainwater collected during the same storm. This is in line with the finding that most $\mathrm{NO}_{\mathrm{x}}$ in the lightning runs is transported out of the domain. However, some $\mathrm{HNO}_{3}$ is formed in the 2-D lightning sensitivity runs (Fig. 10, see also Sect. 7). In the LTN3D run, on the other hand, the formation of $\mathrm{HNO}_{3}$ due to lightning NO production does not lead to significant increases in average $\mathrm{HNO}_{3}$ volume mixing ratios.

Fig. 12b shows budget terms for $\mathrm{HNO}_{3}$ in the gas phase $\left(\mathrm{HNO}_{3(\mathrm{~g})}\right)$ from the LTN3D run. Subsequently, the subscript "g" for gas phase will usually be omitted. Unless otherwise noted, " $\mathrm{HNO}_{3}$ " always refers to gas phase $\mathrm{HNO}_{3}$, not including $\mathrm{HNO}_{3}$ which is dissolved or taken up by ice. The same convention will be used for other soluble trace gases. The budget term for the exchange between gas phase and hy-

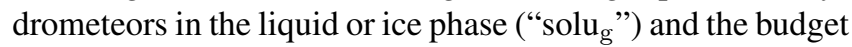
term for the parameterized turbulence ("turb") are combined into one term in order to mask out local compensations of these terms, which mainly occur due to a relatively long lived layer of thin clouds which forms during the first day of the TOGA COARE model runs and from which later deep convection develops. Net chemical production of $\mathrm{HNO}_{3}$ is calculated to predominantly take place in the lower troposphere where $\mathrm{OH}$ concentrations are high, and is largely balanced by scavenging within the domain.

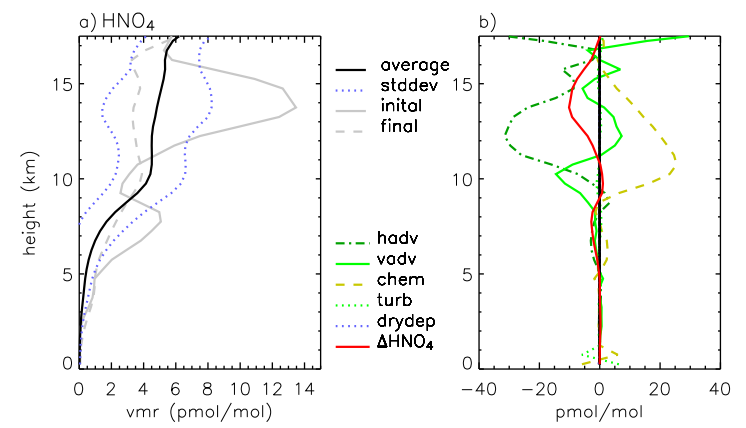

Fig. 13. As Fig. 11 for $\mathrm{HNO}_{4}$.

\subsubsection{Pernitric Acid $\left(\mathrm{HNO}_{4}\right)$}

$\mathrm{HNO}_{4}$ (Figs. 10c and 13) is thermally quite unstable in the lower troposphere, and therefore appreciable amounts are only calculated in the upper troposphere. Fig. 13 shows considerable net formation of $\mathrm{HNO}_{4}$ in the upper troposphere, which is in line with von Kuhlmann (2001).

\subsection{Chemistry budget of nitrogen compounds}

Table 6 shows net chemistry budget terms for PAN, $\mathrm{HNO}_{3}$, $\mathrm{HNO}_{4}$, and $\mathrm{NO}_{\mathrm{x}}$. In the NOLTN run the loss of PAN largely balances the source terms of $\mathrm{NO}_{\mathrm{x}}$ and $\mathrm{HNO}_{3}$ in the lower troposphere. This is in line with Wang et al. (2001), who used their single column model to study the effects of deep convection during PEM-Tropics B and found that in the lower troposphere, the thermal decomposition of PAN transported by subsidence provided the necessary $\mathrm{NO}_{\mathrm{x}}$ source to account for scavenging and deposition of $\mathrm{HNO}_{3}$. Wang and Prinn (2000) did not include PAN in their cloud resolving model study, and found that in a run in which they did not assume lightning NO production, gas phase chemistry acted to remove more than $30 \%$ of the total $\mathrm{NO}_{\mathrm{x}}$ mass within $30 \mathrm{~h}$. During the 7-day NOLTN run, on the other hand, the total tropospheric $\mathrm{NO}_{\mathrm{x}}$ column density changes by only $\sim 5 \%$ (Table 5), mainly due to the decomposition of PAN which is horizontally advected into the model domain (compare Section 4.4.1).

\section{Ozone}

\subsection{Ozone evaluation}

Table 7 shows tropical Pacific ozone mixing ratios and photochemical net tendencies from selected studies. The loss tendencies in percent per day in the LTN3D run are similar to the ones calculated by Crawford et al. (1997) for their "low $\mathrm{NO}_{\mathrm{x}}$ regime" (compare Sect. 4.2). Wang and Prinn (2000), on the other hand, found net ozone production in the lower troposphere in their REF run. 
Table 6. Height integrated net chemistry budget terms ${ }^{1}$ as defined in Eq. (M5) for the last six days of various lightning sensitivity runs.

\begin{tabular}{|c|c|c|c|c|}
\hline & $\mathrm{LT}^{\mathrm{a}}$ & $\mathrm{MT}^{\mathrm{a}}$ & $\mathrm{UT}^{\mathrm{a}}$ & $\mathrm{TC}^{\mathrm{a}}$ \\
\hline \multicolumn{5}{|c|}{ LTN3D } \\
\hline $\mathrm{NO}_{\mathrm{x}}$ & 0.20 & -0.13 & -0.09 & -0.02 \\
\hline PAN & -1.24 & -0.19 & -0.05 & -1.48 \\
\hline $\mathrm{HNO}_{3}$ & 1.00 & 0.29 & 0.04 & 1.32 \\
\hline $\mathrm{HNO}_{4}$ & -0.01 & 0.02 & 0.10 & 0.12 \\
\hline \multicolumn{5}{|c|}{ NOLTN } \\
\hline $\mathrm{NO}_{\mathrm{x}}$ & 0.37 & -0.04 & 0.00 & 0.34 \\
\hline PAN & -1.52 & -0.27 & -0.06 & -1.85 \\
\hline $\mathrm{HNO}_{3}$ & 1.12 & 0.33 & 0.02 & 1.46 \\
\hline $\mathrm{HNO}_{4}$ & -0.01 & -0.02 & 0.04 & 0.01 \\
\hline \multicolumn{5}{|c|}{ LTN1 } \\
\hline $\mathrm{NO}_{\mathrm{x}}$ & -0.95 & -1.30 & -0.76 & -3.01 \\
\hline PAN & -1.41 & -0.21 & -0.05 & -1.67 \\
\hline $\mathrm{HNO}_{3}$ & 2.28 & 1.34 & 0.52 & 4.13 \\
\hline $\mathrm{HNO}_{4}$ & -0.01 & 0.15 & 0.25 & 0.39 \\
\hline \multicolumn{5}{|c|}{ LTN2 } \\
\hline $\mathrm{NO}_{\mathrm{x}}$ & -0.58 & -0.93 & -0.53 & -2.05 \\
\hline PAN & -1.43 & -0.22 & -0.05 & -1.69 \\
\hline $\mathrm{HNO}_{3}$ & 1.93 & 1.03 & 0.33 & 3.30 \\
\hline $\mathrm{HNO}_{4}$ & -0.01 & 0.11 & 0.22 & 0.33 \\
\hline \multicolumn{5}{|c|}{ LTNWP } \\
\hline $\mathrm{NO}_{\mathrm{x}}$ & -3.38 & -3.56 & -1.67 & -8.60 \\
\hline PAN & -1.34 & -0.17 & -0.04 & -1.57 \\
\hline $\mathrm{HNO}_{3}$ & 4.56 & 3.33 & 1.35 & 9.24 \\
\hline $\mathrm{HNO}_{4}$ & 0.00 & 0.34 & 0.26 & 0.60 \\
\hline
\end{tabular}

${ }^{\text {a }}$ Same as in Table 5.

${ }^{1}$ In $10^{14}$ molecule $\mathrm{cm}^{-2}$ day $^{-1}$.

\subsection{Ozone budget}

Table 8 shows calculated ozone column densities as well as time, height, and horizontally integrated tendency terms for ozone for the last six days of all runs but the LTNHWP run. The net chemistry term in the tropospheric column is dominated by net losses in the lower troposphere, where these losses are more than compensated by vertical advection. Ozone coming from the upper and mid-troposphere is in part advected horizontally out of the domain at low altitudes in all runs (compare also discussion of the mid-tropospheric tracer in Sect. 4.2.2 of Salzmann et al., 2004). Fig. 14 shows the temporal evolution of the terms in Table 8 for the LTN3D run. The ozone tendency in the upper tropospheric is influenced by horizontal advection on relatively short time scales. In the lower troposphere chemistry plays a relatively much larger role for the variability of the ozone tendency. Photochemical net loss decreases below clouds due to decreased photolysis and occasionally increases in association with enhanced photolysis at low cloud tops (at $\sim 5 \mathrm{~km}$ in Fig. 15, see also discussion in Sect. M4.1).

\subsection{Stratosphere Troposphere Exchange}

The column integrated vertical advection tendencies in Table 8 are small and negative for the tropospheric column from the surface to $\sim 16 \mathrm{~km}$ as a consequence of a small net upwards transport of ozone from below $\sim 16 \mathrm{~km}$. This time integrated flux divergence will loosely be referred to as "Stratosphere Troposphere Exchange" (STE), although the definition of the tropopause at $\sim 16 \mathrm{~km}$ is arbitrary and not based on physical principles. Furthermore, the diagnosed STE is influenced by the method of prescribing the VLSAT (compare Section 1.2). The net vertical flux across $z_{m}=$ $19.5 \mathrm{~km}$ is scaled to a value which is calculated using $\bar{w}_{\text {obs }}$ (see Sect. 1.2.1). This technique ensures a net vertical flux 
Table 7. Tropical Pacific ozone mixing ratios and photochemical net tendencies from selected studies.

\begin{tabular}{|c|c|c|c|c|}
\hline Reference & $\begin{array}{l}\text { height } \\
(\mathrm{km})\end{array}$ & $\begin{array}{l}\text { ozone } \\
\left(\frac{\mathrm{nmol}}{\mathrm{mol}}\right)\end{array}$ & $\begin{array}{l}\text { net tend. } \\
\left(\frac{\mathrm{nmol}}{\text { mol day }}\right)\end{array}$ & $\%$ per day $^{1}$ \\
\hline $\begin{array}{c}\text { Thompson et al. (1993) } \\
5^{\circ} \mathrm{S} \\
0^{\circ} \\
10^{\circ} \mathrm{N}\end{array}$ & $\begin{array}{l}\text { near surface } \\
\text { near surface } \\
\text { near surface }\end{array}$ & $\begin{array}{c}\text { mean } \\
6 \\
10 \\
20\end{array}$ & $\begin{array}{l}\text { diurn. aver. } \\
\quad-0.5 \\
-1.3 \\
-2.3\end{array}$ & $\begin{array}{c}- \\
-8.3 \\
-13.0 \\
-11.5\end{array}$ \\
\hline $\begin{array}{c}\text { Crawford et al. (1997) } \\
\text { low } \mathrm{NO}_{\mathrm{x}}\end{array}$ & $\begin{array}{c}0-1 \\
1-2 \\
2-4 \\
4-6 \\
6-8 \\
8-10\end{array}$ & $\begin{array}{c}\text { median }^{2} \\
18.9 \\
19.7 \\
21.5 \\
16.9 \\
17.5 \\
18.9\end{array}$ & $\begin{array}{c}\text { diurn. aver. } \\
-2.00 \\
-1.92 \\
-2.19 \\
-0.90 \\
-0.69 \\
-0.07\end{array}$ & $\begin{array}{c}-11.1 \\
-9.7 \\
-10.2 \\
-5.3 \\
-3.9 \\
0.04\end{array}$ \\
\hline high $\mathrm{NO}_{\mathrm{x}}$ & $\begin{array}{c}0-1 \\
1-2 \\
2-4 \\
4-6 \\
6-8 \\
8-10\end{array}$ & $\begin{array}{l}25.8 \\
29.4 \\
54.0 \\
50.4 \\
45.3 \\
40.1\end{array}$ & $\begin{array}{l}-1.77 \\
-2.23 \\
-0.11 \\
0.35 \\
0.99 \\
1.62\end{array}$ & $\begin{array}{c}-7.0 \\
-7.6 \\
-0.02 \\
0.7 \\
2.2 \\
4.0\end{array}$ \\
\hline $\begin{array}{l}\text { Kondo et al. (1997) } \\
\text { marine/tropical }\end{array}$ & $\begin{array}{c}0-1 \\
1-4 \\
4-7 \\
7-12\end{array}$ & $\begin{array}{c}\text { median }^{3} \\
19.0 \\
20.7 \\
15.7 \\
38.6\end{array}$ & $\begin{array}{l}- \\
- \\
- \\
-\end{array}$ & $\begin{array}{l}- \\
- \\
- \\
-\end{array}$ \\
\hline $\begin{array}{c}\text { Wang and Prinn (2000) } \\
\text { REF } \\
\text { LTN } \\
\text { LTNH }\end{array}$ & $\begin{array}{l}0-5 \\
0-5 \\
0-5\end{array}$ & $\begin{array}{c}\text { range }^{4} \\
6-11 \\
6-11 \\
5-9\end{array}$ & $\begin{array}{c}\text { range }^{5} \\
0.0 \text { to } 0.2 \\
-0.2 \text { to }-0.5 \\
-1.0 \text { to }-2.5\end{array}$ & $\begin{array}{l}- \\
- \\
-\end{array}$ \\
\hline Mari et al. (2003) & $0-5$ & $\begin{array}{l}\text { range }^{6} \\
8-24\end{array}$ & $\begin{array}{c}\text { range }^{6} \\
-0.5 \text { to }-3.0\end{array}$ & - \\
\hline $\begin{array}{l}\text { this study } \\
\qquad \text { LTN3D }\end{array}$ & $\begin{array}{c}0-2 \\
2-4 \\
4-6 \\
6-8 \\
8-10 \\
10-14\end{array}$ & $\begin{array}{c}\text { median } \\
14.5 \\
20.6 \\
30.1 \\
34.6 \\
30.4 \\
28.3\end{array}$ & $\begin{array}{c}\text { diurn. aver. } \\
-1.9 \\
-2.5 \\
-3.2 \\
-2.5 \\
-0.9 \\
0.3\end{array}$ & $\begin{array}{c}-13.3 \\
-12.0 \\
-10.7 \\
-7.1 \\
0.0 \\
0.9\end{array}$ \\
\hline
\end{tabular}

${ }^{1}$ Estimates are based on daytime median or mean ozone mixing ratio and diurnal averaged tendency, and are merely indicated to facilitate comparisons.

${ }^{2}$ For $\mathrm{SZA}<70^{\circ}$.

${ }^{3}$ For $\mathrm{SZA}<60^{\circ}$.

${ }^{4}$ At the end of a $30 \mathrm{~h}$ simulation; estimated from Fig. 11 of Wang and Prinn (2000).

${ }^{5}$ For a 30 h simulation; estimated from Fig. 9 of Wang and Prinn (2000).

${ }^{6}$ For 9:30 to 17:15 local solar time; estimated from Fig. 13 of Mari et al. (2003). 
Table 8. As Table 5 for ozone.

\begin{tabular}{|c|c|c|c|c|}
\hline & $\mathrm{LT}^{\mathrm{a}}$ & $\mathrm{MT}^{\mathrm{a}}$ & $\mathrm{UT}^{\mathrm{a}}$ & $\mathrm{TC}^{\mathrm{a}}$ \\
\hline \multicolumn{5}{|c|}{ LTN3D } \\
\hline av. column density ${ }^{1}$ & 1.82 & 1.90 & 1.29 & 5.01 \\
\hline vertical advection ${ }^{2}$ & 0.18 & -0.32 & 0.10 & -0.04 \\
\hline horizontal advection $^{2}$ & 0.05 & 0.31 & -0.19 & 0.18 \\
\hline chemistry $^{2}$ & -0.22 & -0.12 & 0.01 & -0.32 \\
\hline turbulence param. ${ }^{2}$ & 0.03 & -0.03 & 0.01 & 0.01 \\
\hline dry deposition ${ }^{2}$ & -0.03 & - & - & -0.03 \\
\hline total tendency ${ }^{2,3}$ & 0.00 & -0.15 & -0.06 & -0.21 \\
\hline \multicolumn{5}{|c|}{ NOLTN } \\
\hline av. column density ${ }^{1}$ & 1.85 & 1.83 & 1.25 & 4.93 \\
\hline vertical advection ${ }^{2}$ & 0.36 & -0.12 & -0.30 & -0.06 \\
\hline horizontal advection $^{2}$ & -0.14 & 0.16 & 0.20 & 0.23 \\
\hline chemistry $^{2}$ & -0.22 & -0.12 & 0.01 & -0.33 \\
\hline turbulence param. ${ }^{2}$ & 0.06 & -0.06 & 0.00 & 0.01 \\
\hline dry deposition ${ }^{2}$ & -0.03 & - & - & -0.03 \\
\hline total tendency ${ }^{2,3}$ & 0.04 & -0.14 & -0.08 & -0.18 \\
\hline \multicolumn{5}{|c|}{ LTN1 } \\
\hline av. column density ${ }^{1}$ & 1.88 & 1.92 & 1.27 & 5.07 \\
\hline vertical advection ${ }^{2}$ & 0.37 & -0.13 & -0.29 & -0.06 \\
\hline horizontal advection $^{2}$ & -0.17 & 0.14 & 0.15 & 0.12 \\
\hline chemistry $^{2}$ & -0.19 & -0.06 & 0.06 & -0.19 \\
\hline turbulence param. ${ }^{2}$ & 0.07 & -0.06 & 0.01 & 0.01 \\
\hline dry deposition ${ }^{2}$ & -0.03 & - & - & -0.03 \\
\hline total tendency ${ }^{2,3}$ & 0.05 & -0.11 & -0.08 & -0.15 \\
\hline \multicolumn{5}{|c|}{ LTN2 } \\
\hline av. column density ${ }^{1}$ & 1.87 & 1.90 & 1.27 & 5.04 \\
\hline vertical advection ${ }^{2}$ & 0.37 & -0.13 & -0.29 & -0.06 \\
\hline horizontal advection $^{2}$ & -0.16 & 0.15 & 0.16 & 0.14 \\
\hline chemistry $^{2}$ & -0.20 & -0.07 & 0.05 & -0.22 \\
\hline turbulence param. ${ }^{2}$ & 0.06 & -0.06 & 0.01 & 0.01 \\
\hline dry deposition ${ }^{2}$ & -0.03 & - & - & -0.03 \\
\hline total tendency ${ }^{2,3}$ & 0.04 & -0.12 & -0.08 & -0.15 \\
\hline \multicolumn{5}{|c|}{ LTNWP } \\
\hline av. column density ${ }^{1}$ & 1.90 & 2.01 & 1.29 & 5.20 \\
\hline vertical advection ${ }^{2}$ & 0.38 & -0.15 & -0.29 & -0.05 \\
\hline horizontal advection $^{2}$ & -0.21 & 0.12 & 0.12 & 0.04 \\
\hline chemistry $^{2}$ & -0.16 & 0.00 & 0.09 & -0.07 \\
\hline turbulence param. ${ }^{2}$ & 0.07 & -0.07 & 0.01 & 0.01 \\
\hline dry deposition ${ }^{2}$ & -0.03 & - & - & -0.03 \\
\hline total tendency ${ }^{2,3}$ & 0.05 & -0.09 & -0.07 & -0.11 \\
\hline
\end{tabular}

\footnotetext{
${ }^{\text {a }}$ Same as in Table 5.

${ }^{1}$ In $10^{17}$ molecule $\mathrm{cm}^{-2}$. One Dobson unit (DU) is $2.69 \cdot 10^{16}$ molecule $\mathrm{cm}^{-2}$. The average tropospheric ozone column in the LTN1 run is $4.95 \cdot 10^{17}$ molecule $\mathrm{cm}^{-2}$ or $18.4 \mathrm{DU}$.

${ }^{2}$ In $10^{17}$ molecule $\mathrm{cm}^{-2}$ day $^{-1}$.

${ }^{3}$ Diagnosed from the change of column densities, the values are, however, identical to the rounded sum of unrounded values for the individual processes.
} 

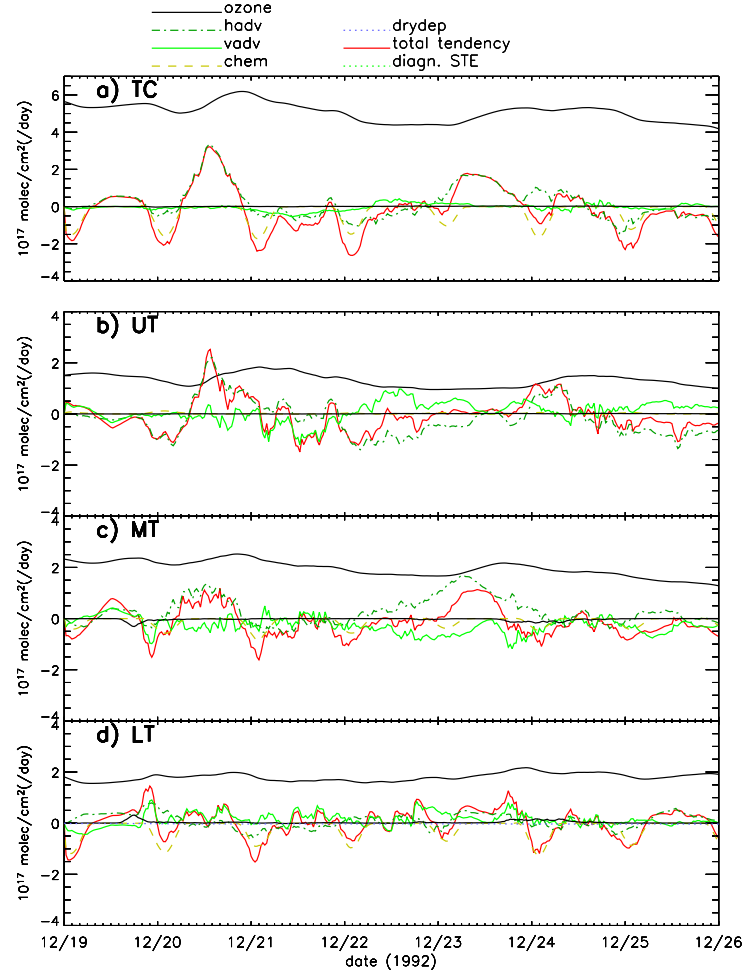

Fig. 14. (a) Time series of average column density and domainaveraged, height integrated and $30 \mathrm{~min}$ time-averaged tendency terms for ozone from the LTN3D run. The model domain is divided into MT, UT, and LT as in Table 5. Ozone column densities (black lines) are expressed in $10^{17}$ molecules $\mathrm{cm}^{-2}$ and all other terms are expressed in $10^{17}$ molecules $\mathrm{cm}^{-2}$ day $^{-1}$. "Exchange between stratosphere and troposphere (STE)" is diagnosed using $\bar{w}_{\text {obs }}$ at $\sim 16 \mathrm{~km}$ altitude as described in the text.

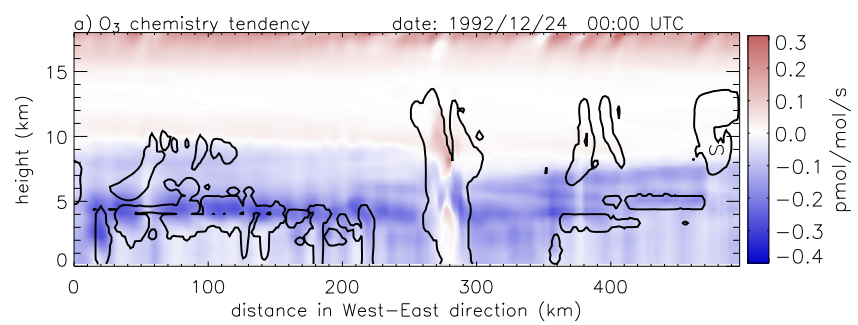

Fig. 15. Gridded net chemistry tendencies for ozone from the LTN1 run: time average calculated for $30 \mathrm{~min}$ time integral from 23 December 1992, 23:30 UTC to 24 December 1992, 24:00 UTC and instantaneous total hydrometeor mixing ratio contour $\left(q_{\text {totm }}=\right.$ $0.01 \mathrm{~g} \mathrm{~kg}^{-1}$ ) for 24 December 1992, 24:00 UTC.

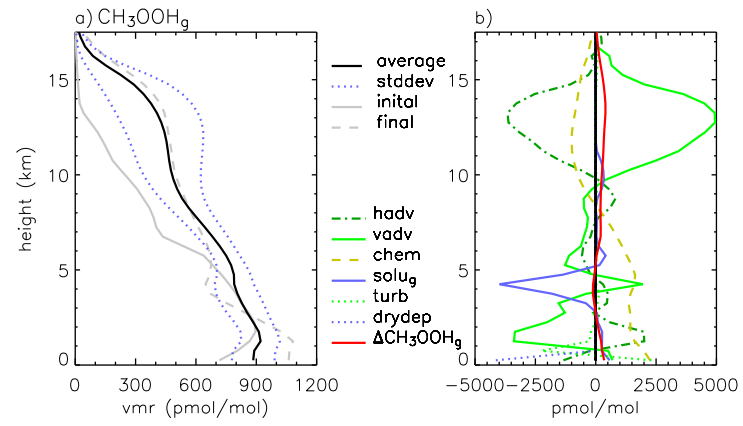

Fig. 16. As Fig. 11 for $\mathrm{CH}_{3} \mathrm{OOH}$ in the gas phase.

at $z_{m}$ which is consistent with a small positive $\bar{w}_{o b s}$ at this altitude reflecting average ascent. The positive sign of $\bar{w}_{o b s}$ is consistent with the tropics being a region of average lower stratospheric ascent and troposphere to stratosphere transport (Holton et al., 1995; Corti et al., 2005). The STE in Fig. 14a is diagnosed from the ozone concentration in the CSRMC and from $\bar{w}_{\text {obs }}$ at $\sim 16 \mathrm{~km}$. The diagnosed values are, however, largely consistent with the residual calculated by vertically integrating the vertical advection tendency. This consistency is in part assured by the technique of scaling the fluxes. However, the corresponding inconsistency in sensitivity runs without applying a scaling is very moderate (not shown).

\section{Hydrogen compounds}

\subsection{Methyl Hydroperoxide $\left(\mathrm{CH}_{3} \mathrm{OOH}\right)$}

The transport of hydrogen peroxide $\left(\mathrm{CH}_{3} \mathrm{OOH}\right.$, moderately soluble) from the lower to the upper troposphere in deep convective clouds is an important source of upper tropospheric $\mathrm{HO}_{\mathrm{x}}$ under tropical conditions (Prather and Jacob, 1997; Jaeglé et al., 1997, 2001; Wang et al., 2001). In the LTN3D run, $\mathrm{CH}_{3} \mathrm{OOH}$ has a large chemical in-situ source in the lower troposphere (Fig. 16). Uptake by hydrometeors is found to be important only in a thin layer below $5 \mathrm{~km}$ where rain drops form (compare Fig. 7), but on the whole scavenging does not prevent efficient upward transport of $\mathrm{CH}_{3} \mathrm{OOH}$ in agreement with previous studies (e.g. Barth et al., 2007b). The domain average volume mixing ratios in Fig. 16a are in line with average vertical profiles over the tropical Pacific during PEM-West A and PEM-Tropics A presented by Singh et al. (1998).

\subsection{Hydrogen Peroxide $\left(\mathrm{H}_{2} \mathrm{O}_{2}\right)$}

Hydrogen peroxide is far more water soluble than methyl hydroperoxide. It has been argued that the transport of $\mathrm{H}_{2} \mathrm{O}_{2}$ in deep convective clouds is very inefficient, and that consequently large contributions of deep convective $\mathrm{H}_{2} \mathrm{O}_{2}$ transport to the abundance of $\mathrm{HO}_{\mathrm{x}}$ in the upper troposphere are 


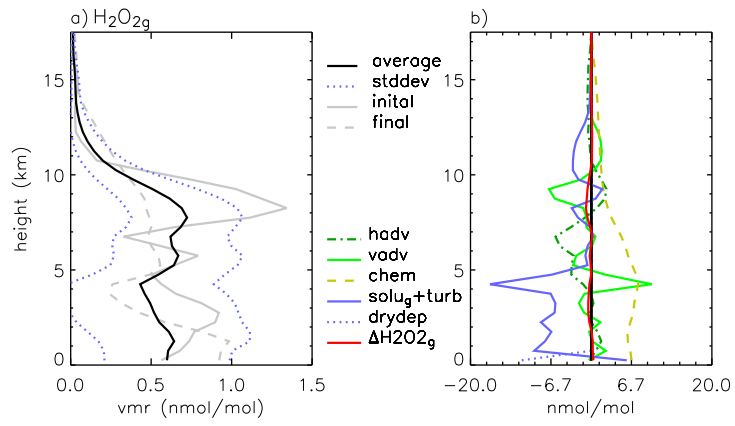

Fig. 17. As Fig. 11 for $\mathrm{H}_{2} \mathrm{O}_{2}$.

unlikely to occur (e.g. Prather and Jacob, 1997; Crawford et al., 1999). Crawford et al. (1999) suggested that elevated $\mathrm{H}_{2} \mathrm{O}_{2}$ levels at $11-12 \mathrm{~km}$ could be caused by elevated $\mathrm{HO}_{\mathrm{x}}$ levels. Mari et al. (2000), on the other hand, found that observations of enhanced upper tropospheric $\mathrm{H}_{2} \mathrm{O}_{2}$ concentrations after deep convection could be caused by the rejection of $\mathrm{H}_{2} \mathrm{O}_{2}$ from freezing hydrometeors. The simulated vertical distribution of $\mathrm{H}_{2} \mathrm{O}_{2}$ is indeed rather sensitive to assumptions regarding ice uptake and rejection from freezing hydrometeors (compare Barth et al., 2001, 2007b,a; Salzmann, 2005; Salzmann et al., 2007), but the retention coefficient is still uncertain and depends on details of the freezing process (Stuart and Jacobson, 2003, 2004). In this study, efficient monolayer uptake of $\mathrm{H}_{2} \mathrm{O}_{2}$ on ice crystals is assumed (compare discussion in Section 1.6). Assuming $\mathrm{H}_{2} \mathrm{O}_{2}$ to be completely released from hydrometeors during freezing and neglecting $\mathrm{H}_{2} \mathrm{O}_{2}$ uptake on ice would have a considerable influence on the $\mathrm{H}_{2} \mathrm{O}_{2}$ budget in the domain, but has a negligible influence on the ozone budget in a simulation with a $500 \mathrm{~km}$ 2-D domain (Salzmann, 2005).

Fig. 17 shows modeled profiles and budget terms for $\mathrm{H}_{2} \mathrm{O}_{2}$ from the LTN3D run. Net photochemical $\mathrm{H}_{2} \mathrm{O}_{2}$ formation is calculated to occur throughout the troposphere with a maximum at about $5 \mathrm{~km}$. The sudden decrease of uptake by hydrometeors between $\sim 5 \mathrm{~km}$ and $6 \mathrm{~km}$ height is due to rain being more efficient at removing $\mathrm{H}_{2} \mathrm{O}_{2}$ than cloud droplets. Monolayer uptake on ice and subsequent scavenging (horizontal advection of $\mathrm{H}_{2} \mathrm{O}_{2}$ taken up by ice across the lateral boundaries is negligibly small compared to the other terms) causes large losses above $10 \mathrm{~km}$. Around $10 \mathrm{~km} \mathrm{H}_{2} \mathrm{O}_{2}$ is released from freezing cloud droplets in a relatively thin layer. Such a peak does not occur for $\mathrm{HNO}_{3}$ (Fig. 12), which is assumed to be completely retained in hydrometeors during freezing.

\subsection{Formaldehyde (HCHO)}

Formaldehyde (HCHO) is a major intermediate in the oxidation chain of methane. Its effective Henry's law coefficient used in the CSRMC is $3.2 \cdot 10^{3} \mathrm{~mol} \mathrm{l}^{-1} \mathrm{~atm}^{-1}$, adopted from

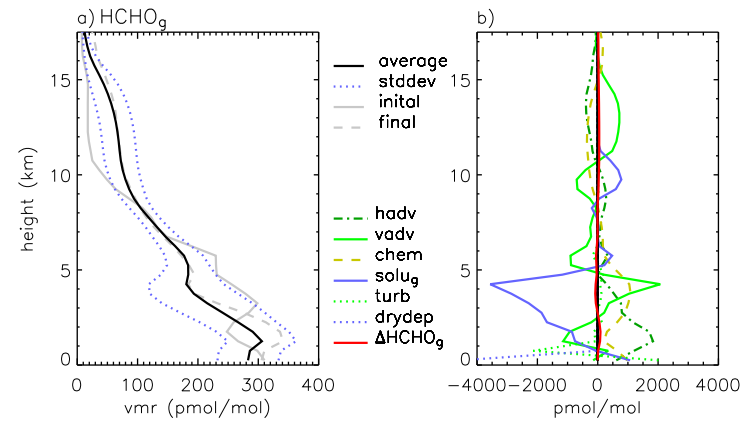

Fig. 18. As Fig. 11 for $\mathrm{HCHO}$.

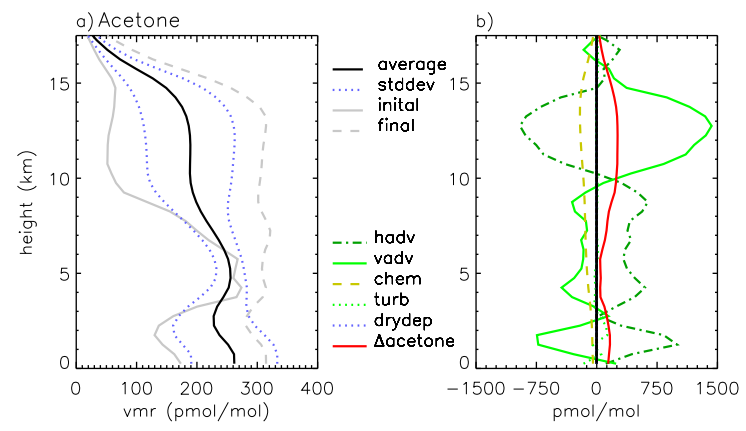

Fig. 19. As Fig. 11 for acetone.

Staudinger and Roberts (1996), and its retention coefficient is assumed to be 0.02 (Sect. 1.6). Uptake by ice directly from the gas phase is not taken into account. In the LTN3D run, a significant amount of formaldehyde is transported to the upper troposphere in spite of relatively efficient scavenging below $\sim 5 \mathrm{~km}$ (Fig. 18). Positive contributions from the "solu" term are due to the release of formaldehyde from freezing hydrometeors.

\subsection{Acetone $\left(\mathrm{CH}_{3} \mathrm{COCH}_{3}\right)$}

The photolysis of acetone $\left(\mathrm{CH}_{3} \mathrm{COCH}_{3}\right)$ is believed to be another important contributor to the $\mathrm{HO}_{\mathrm{x}}$ budget in the upper troposphere (e.g. Singh et al., 1995; Folkins et al., 1998; Jaeglé et al., 2001). Furthermore, acetone is found to play an important role for the conversion of $\mathrm{NO}_{\mathrm{x}}$ to PAN (Singh et al., 1995). In remote regions, the abundance of acetone has been shown to be under-predicted by MATCH-MPIC, possibly due to an oceanic source (Singh et al., 2001; Jacob et al., 2002) which is not represented in the model (von Kuhlmann et al., 2003b). Recently, Blitz et al. (2004) presented measurements which showed quantum yields for acetone to be temperature dependent. Based on these measurements, Arnold et al. (2004) calculated the estimated lifetime of acetone in the upper troposphere to increase from $\sim 75$ to $\sim 250$ days at mid latitudes and from $\sim 10$ to $\sim 20$ days in the 
tropics. In present study, the temperature dependence of the quantum yields for acetone is not taken into account. The effect of assuming too high quantum yields in the upper troposphere is to over-estimate the importance of acetone for the upper tropospheric $\mathrm{HO}_{\mathrm{x}}$ budget. On the other hand, the effect of the lateral boundary values from MATCH-MPIC most likely being too low is to under-estimate the effect of the deep convective transport of acetone on the upper troposphere.

Acetone is emitted (mainly from biogenic sources) and formed photochemically from the oxidation of numerous non-methane hydrocarbons (e.g. from propane, which in oceanic regions is also underpredicted by MATCH-MPIC, see von Kuhlmann, 2001). In the CSRMC, higher alkenes were not included. Although known sources of higher alkenes are concentrated in continental regions, not including these compounds into the CSRMC could lead to underestimating the gross formation and consequently to overestimating the net loss of acetone in the CSRMC. All in all, the uncertainties associated with acetone in the CSRMC are particularly large.

In the LTN3D run, on average, net photochemical loss of acetone is calculated to occur inside the domain throughout the depth of the troposphere (Fig. 19b). A 2-D sensitivity run without acetone has yielded that not including acetone would not change the main results of this study (not shown).

\section{Scavenging: Examples}

Figs. 20 and 21 show volume mixing ratio contours of nitric acid, hydrogen peroxide, formaldehyde, and methyl hydroperoxide calculated for 24 December 1992, 2:30 UTC and for 21 December 1992, 7:30 UTC for the LTN1 run. The enhancements of $\mathrm{HNO}_{3}$ in the upper troposphere are caused by in-situ formation and not by transport, as a comparison of Fig. 20a to Fig. 22 for the NOLTN run shows. Local maxima of the $\mathrm{HNO}_{3}$ and $\mathrm{H}_{2} \mathrm{O}_{2}$ mixing ratios close to $\mathrm{x}=250 \mathrm{~km}$ in Figs. $20 \mathrm{a}$ and $\mathrm{b}$ are generated by a combination of upper tropospheric production, uptake, transport in sedimenting hydrometeors, the evaporation of these hydrometeors, and the associated release of the compounds to the gas phase. In Fig. 21b, a region of low $\mathrm{H}_{2} \mathrm{O}_{2}$ volume mixing ratios is found in the anvil outflow. The existence of this "low $\mathrm{H}_{2} \mathrm{O}_{2}$ anvil" is linked to uptake and subsequent removal by precipitation during the upwards transport of air. Such a "low $\mathrm{H}_{2} \mathrm{O}_{2}$ anvil" is also found in a sensitivity run in which $\mathrm{H}_{2} \mathrm{O}_{2}$ is assumed not to be taken up by ice (not shown). The anvil outflow of $\mathrm{HCHO}$ and $\mathrm{CH}_{3} \mathrm{OOH}$ extends beyond the $q_{\text {totm }}=0.01 \mathrm{~g} \mathrm{~kg}^{-1}$ contour. Outflow extending beyond the ice anvil is also characteristic of insoluble gases.

\section{Description of the MATCH-MPIC runs}

The 3-D global chemistry-transport model MATCH-MPIC is a "semi-offline" model which reads in basic meteorologi-

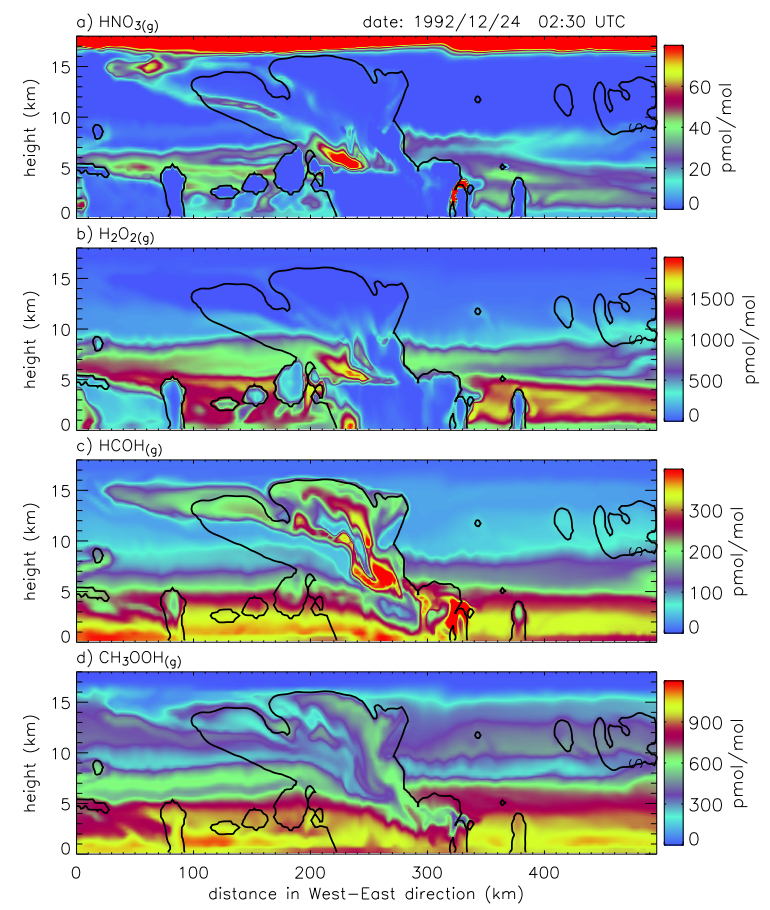

Fig. 20. Volume mixing ratio contours for (a) $\mathrm{HNO}_{3}$, (b) $\mathrm{H}_{2} \mathrm{O}_{2}$, (c) $\mathrm{H}_{2} \mathrm{O}_{2}$, and (d) $\mathrm{CH}_{3} \mathrm{OOH}$ on 24 December 1992, 2:30 UTC and $q_{\text {totm }}=0.01 \mathrm{~g} \mathrm{~kg}^{-1}$ mass mixing ratio contour.

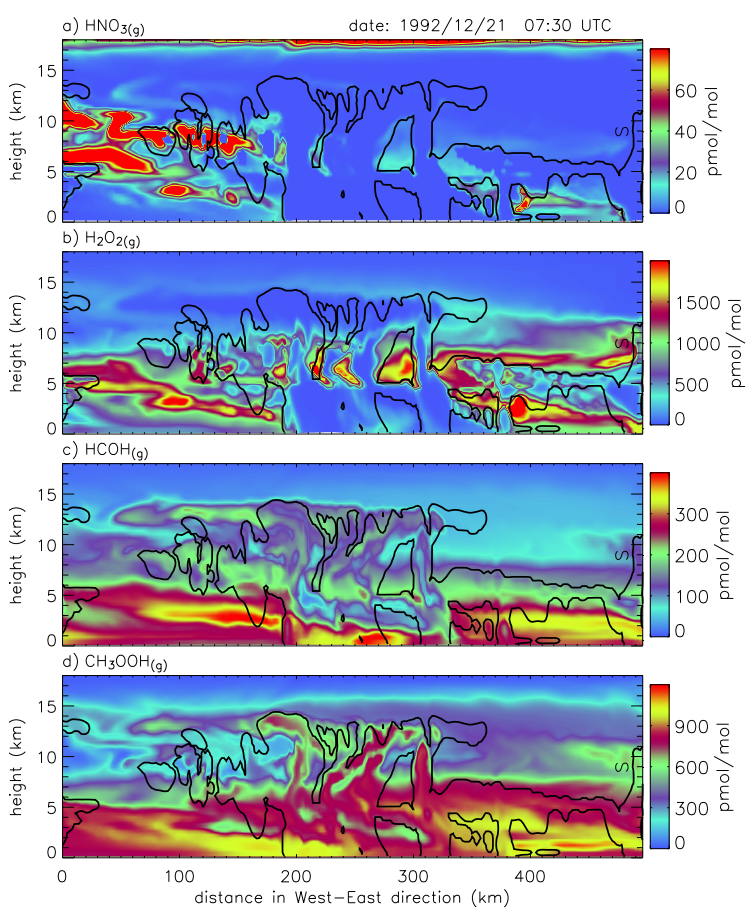

Fig. 21. Same as Fig. 20 for 21 December 1992, 7:30 UTC. 


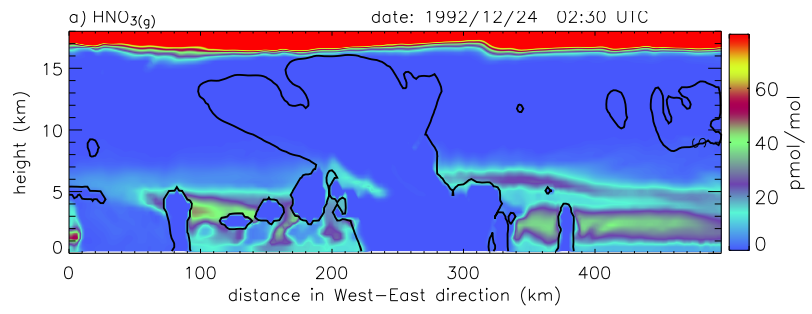

Fig. 22. Same as Fig. 20a for the NOLTN run.

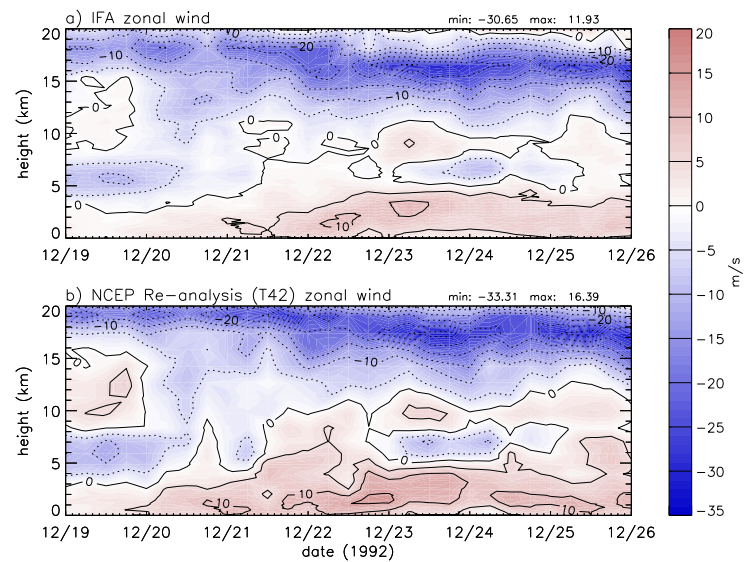

Fig. 23. Time height contours of the zonal wind component (a) from observations during TOGA COARE and (b) from NCEP/NCAR meteorological re-analysis interpolated to T42 and plotted for the column located closest to the center of the TOGA COARE IFA.

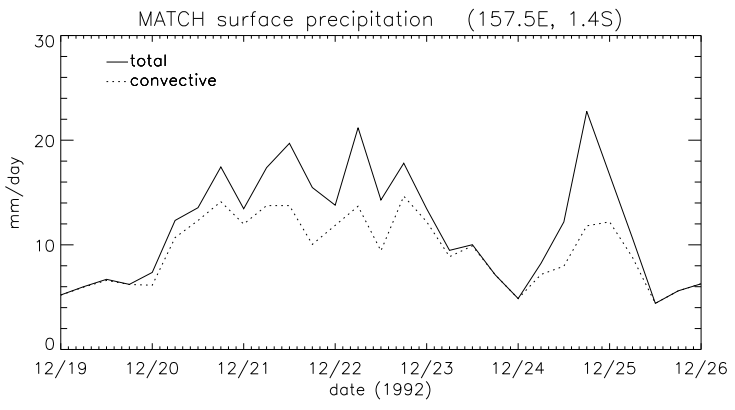

Fig. 24. Two-hourly MATCH-MPIC calculated precipitation rates for the point located closest to the TOGA COARE IFA.

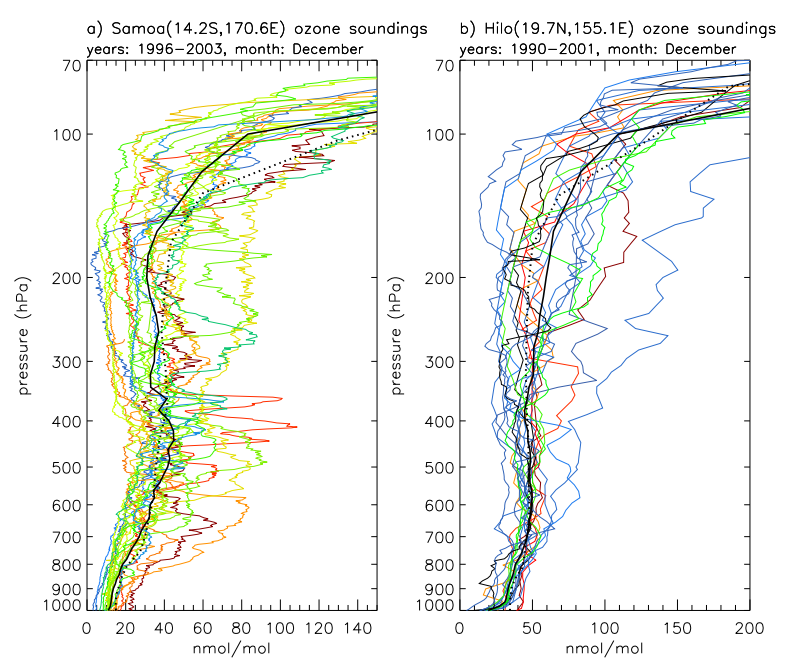

Fig. 25. Ozone profiles at (a) American Samoa and (b) Hilo. Thin lines: soundings launched in December, thick solid line: average of sondes launched in December, dotted line: average from the MATCH-MPIC T42 run for December 1992. Three soundings at Hilo seemed suspicious and were excluded. The sonde data has been retrieved from the World Ozone and Ultraviolet Radiation Data Centre (WOUDC). Both sonde sites were operated by the Climate Monitoring and Diagnostics Laboratory (CMDL) of the National Oceanic and Atmospheric Administration (NOAA, PI: S. Oltmans). The station at Samoa is part of the SHADOZ project (SHADOZ: Southern Hemisphere ADditional OZonesondes, Thompson et al., 2003).

cal data (horizontal wind, geopotential, temperature, surface fluxes of heat and moisture, etc.), and simulates the atmospheric part of the hydrological cycle including the advection of water vapor. Deep convection and rainfall, cloud microphysics, boundary layer turbulence, and cloud fractions are parameterized in MATCH-MPIC. The setup used here is largely identical to the setup routinely used for MATCHMPIC chemical weather forecasts, the details of which can be found in Lawrence et al. (2003). As in the study by von Kuhlmann et al. (2003a) the stratospheric flux of ozone has been reduced artificially through reducing stratospheric ozone concentrations by $50 \%$ before the advection routine and setting them back after that.

The meteorological input data for MATCH-MPIC is prescribed from NCEP/NCAR 40-year meteorological reanalysis (Kalnay et al., 1996) in the present study. Trace gas initial and lateral boundary conditions for the CSRMC have been derived from runs with T42 horizontal resolution, which is about $2.8^{\circ} \times 2.8^{\circ}$, and with 28 vertical levels up to $2 \mathrm{hPa}$. In Sect. M6, runs with T62 horizontal resolution are analyzed. However, T42 resolution is sufficient to capture the general structure of the observed zonal wind during the 7-day episode (Fig. 23). The temporal evolution of the surface precipitation calculated by MATCH-MPIC (Fig. 24) is similar to the temporal evolution simulated by the CSRMC (Fig. 4), 
but the amount differs by roughly a factor of two. (If we use the same input dataset as the GCSS Science Team (1993) instead of the dataset from Ciesielski et al. (2003), we find significantly lower (on the order of 50\%) precipitation rates (not shown) which are very similar to Fig. 4 of Gregory and Guichard (2002) and in better agreement with the NCEP reanalysis. To the authors' knowledge, these large differences between different input datasets have not yet been addressed in the literature.) A comparison between observed and simulated average ozone profiles for two locations in the Pacific indicates that MATCH-MPIC performs reasonably well (Fig. 25).

\section{References}

Abbatt, J. P. D.: Interaction of $\mathrm{HNO}_{3}$ with water-ice surfaces at temperatures of the free troposphere, Geophys. Res. Lett., 24, 1479-1482, 1997.

Adamson, A. W. and Gast, A. P.: Physical Chemistry of Surfaces, $6^{\text {th }}$ Ed., John Wiley, New York, 1997.

Andronache, C., Donner, L. J., Seman, C. J., Ramaswamy, V., and Hemler, R. S.: Atmospheric sulfur and deep convective clouds in tropical Pacific: A model study, J. Geophys. Res., 104, 40054024, 1999.

Arnold, S. R., Chipperfield, M. P., Blitz, M. A., Heard, D. E., and Pilling, M. J.: Photodissociation of acetone: Atmospheric implications of temperature-dependent quantum yields, Geophys. Res. Lett., 31, L07 110, doi:10.1029/2003GL019 099, 2004.

Atkinson, R., Baulch, D. L., Cox, R. A., Hampson, Jr, R. F., Kerr, J. A., Rossi, M. J., and Troe, J.: Evaluated kinetic and heterogeneous data for atmospheric chemistry: Supplement V, J. Phys. Chem. Ref. Data, 26, 521-1011, 1997.

Atkinson, R., Baulch, D. L., Cox, R. A., R. F. Hampson, J., Kerr, J. A., Rossi, M. J., and Troe, J.: Evaluated kinetic and photochemical data for atmospheric chemistry, Organic species: Supplement VII, J. Phys. Chem. Ref. Data, 28, 191-393, http: / / www.iupac--kinetic.ch.cm.ac.uk/, 1999.

Bartels-Rausch, T., Eichler, B., Zimmermann, P., Gäggeler, H. W., and Ammann, M.: The adsorption enthalpy nitrogen oxides on crystalline ice, Atmos. Chem. Phys., 2, 235-247, 2002.

Barth, M. C., Stuart, A. L., and Skamarock, W. C.: Numerical simulations of the July 10, 1996, Stratospheric-Tropospheric Experiment: Radiation, Aerosols, and Ozone (STERAO)-Deep Convection Experiment storm: Redistribution of soluble tracers, J. Geophys. Res., 106, 12 381-12 400, 2001.

Barth, M. C., Kim, S.-W., Wang, C., Pickering, K. E., Ott, L. E., Stenchikov, G., Leriche, M., Cautenet, S., Pinty, J.-P., Barthe, C., Mari, C., Helsdon, J., Farley, R., Fridlind, A. M., Ackerman, A. S., Spiridonov, V., and Telenta, B.: Cloud-scale model intercomparison of chemical constituent transport in deep convection, Atmos. Chem. Phys. Discuss., 7, 8035-8085, 2007a.

Barth, M. C., S.-W, K., Skamarock, W. C., Stuart, A. L., Pickering, K. E., and Ott, L. E.: Simulations of the redistribution of formaldehyde, formic acid, and peroxides in the 10 July 1996 Stratospheric-Tropospheric Experiment: Radiation, Aerosols, and Ozone deep convection storm, J. Geophys. Res., 112, D13 310, doi:10.1029/2006JD008 046, 2007 b.
Blitz, M. A., Heard, D. E., Pilling, M. J., Arnold, S. R., and Chipperfield, M. P.: Pressure and temperature-dependent quantum yields for the photodissociation of acetone between 279 and $327.5 \mathrm{~nm}$, Geophys. Res. Lett., 31, L06 111, doi:10.1028/2003GL018 793, 2004.

Chameides, W. L., Davis, D. D., Bradshaw, J., Rodgers, M., Sandholm, S., and Bai, D. B.: An estimate of the $\mathrm{NO}_{\mathrm{x}}$ production rate in electrified clouds based on $\mathrm{NO}$ observations from the GTE/CITE 1 fall 1983 field operation, J. Geophys. Res., 92, 2153-2156, 1987.

Chou, M.-D., Suarez, M. J., Ho, C.-H., Yan, M. M.-H., and Lee, K.-T.: Parameterizations for cloud overlapping and shortwave single-scattering properties for use in general circulation and cloud ensemble models, J. Climate, 11, 202-214, 1998.

Ciesielski, P. E., Johnson, R. H., Haertel, P. T., and Wang, J.: Corrected TOGA COARE sounding humidity data: Impact on diagnosed properties of convection and climate over the warm pool, J. Climate, 16, 2370-2384, 2003.

Clegg, S. M. and Abbatt, J. P. D.: Uptake of gas-phase $\mathrm{SO}_{2}$ and $\mathrm{H}_{2} \mathrm{O}_{2}$ by ice surfaces: dependence on partial pressure, temperature, and surface acidity, J. Phys. Chem. A, 105, 6630-6636, 2001.

Conklin, M. H., Sigg, A., Neftel, A., and Bales, R. C.: Atmospheresnow transfer function for $\mathrm{H}_{2} \mathrm{O}_{2}$ : Microphysical considerations, J. Geophys. Res., 98, 18 367-18376, 1993.

Corti, T., Luo, B. P., Peter, T., Vömel, H., and Fu, Q.: Mean radiative energy balance and vertical mass fluxes in the equatorial upper troposphere and lower stratosphere, Geophys. Res. Lett., 32, L06 802, doi:10.1029/2004GL021 889, 2005.

Crawford, J., Davis, D., Olson, J., Chen, G., Liu, S., Gregory, G., Barrick, J., Sachse, G., Sandholm, S., Heikes, B., Singh, H., and Blake, D.: Assessment of upper tropospheric $\mathrm{HO}_{\mathrm{x}}$ sources over the tropical Pacific based on NASA GTE/PEM data: Net effect on $\mathrm{HO}_{\mathrm{x}}$ and other photochemical parameters, J. Geophys. Res., 104, 16 255-16273, 1999.

Crawford, J. H., Davis, D. D., Chen, G., Bradshaw, J., Sandholm, S., Kondo, Y., Merill, J., Liu, S., Browell, E., Gregory, G., Anderson, B., Sachse, G., Barrick, J., Blake, D., Talbot, R., and Pueschel, R.: Implications of large shifts in tropospheric $\mathrm{NO}_{\mathrm{x}}$ levels in the remote tropical Pacific, J. Geophys. Res., 102, 28 447-28 468, 1997.

Damian, V., Sandu, A., Damian, M., Potra, F., and Carmichael, G. R.: The kinetic preprocessor KPP - A software environment for solving chemical kinetics, Computers and Chemical Engineering, 26, $1567-1579,2002$.

Damian-Iordache, V.: KPP - Chemistry simulation development environment, Master's thesis, University of Iowa, Iowa City, Iowa, 1996.

DeMore, W. B., Sander, S. P., Howard, C. J., Ravishankara, A. R., Golden, D. M., Kolb, C. E., Hampson, R. F., Kurylo, M. J., and Molina, M. J.: Chemical kinetics and photochemical data for use in stratospheric modeling, Evaluation no. 12 of the nasa panel for data evaluation, Jet Propulsion Laboratory, Pasadena, California, 1997.

Dentener, F. J. and Crutzen, P. J.: Reaction of $\mathrm{N}_{2} \mathrm{O}_{5}$ on tropospheric aerosols: Impact on the global distributions of $\mathrm{NO}_{\mathrm{x}}, \mathrm{O}_{3}$, and $\mathrm{OH}$, J. Geophys. Res., 98, 7149-7163, 1993.

Diehl, K., Mitra, S. K., and Pruppacher, H. R.: A laboratory study of the uptake of $\mathrm{HNO}_{3}$ and $\mathrm{HCl}$ vapor by snow crystals and ice 
spheres at temperatures between $0{ }^{\circ} \mathrm{C}$ and $-40^{\circ} \mathrm{C}$, Atmos. Environ., 29, 975-981, 1995.

Dominé, F. and Thibert, E.: Mechanism of incorporation of trace gases in ice grown from the gas phase, Geophys. Res. Lett., 23, 3627-3630, 1996.

Dominé, F. and Thibert, E.: Comment on "Diffusion of $\mathrm{HNO}_{3}$ in ice", Geophys. Res. Lett., 25, 4389-4390, 1998.

Dransfield, T. J., Perkins, K. K., Donahue, N. M., Anderson, J. G., Sprengnether, M. M., and Demerjian, K. L.: Temperature and pressure dependent kinetics of the gas-phase reaction of the hydroxy radical with nitrogen dioxide, Geophys. Res. Lett., 26, 687-690, 1999.

Folkins, I., Chatfield, R., Singh, H., Chen, Y., and Heikes, B.: Ozone production efficiencies of acetone and peroxides in the upper troposphere, J. Geophys. Res., 25, 1305-1308, 1998.

Friedel, H., Grauer, R., and Marliani, C.: Adaptive mesh refinement for singular current sheets in incompressible magnetohydrodynamic flows, J. Comput. Phys., 134, 190-198, 1997.

Gao, R. S., Popp, P. J., Fahey, D. W., Marcy, T. P., Herman, R. L., Weinstock, E. M., Baumgardner, D. G., Garrett, T. J., Rosenlof, K. H., Thompson, T. L., Bui, P. J., Ridley, B. A., Wofsy, S. C., Toon, O. B., Tolbert, M. A., Kärcher, B., Peter, T., Hudson, P. K., Weinheimer, A. J., and Heymsfield, A. J.: Evidence that nitric acid increases relative humidity in low-temperature cirrus clouds, Science, 303, 516-520, 2004.

GCSS Science Team: The GEWEX Cloud System Study (GCSS), Bull. Am. Met. Soc., 74, 387-399, 1993.

Gregory, D. and Guichard, F.: Aspects of the parametrization of organized convection: Contrasting cloud resolving model and single-column model realizations, Q. J. R. Meteorol. Soc., 128, 625-646, 2002.

Grell, G. A., Peckham, S. E., Schmitz, R., McKeen, S. A., Wilczak, J., and Eder, B.: Fully coupled "online" chemistry within the WRF model, Atmos. Environ., 39, 6957-6975, 2005.

Hairer, E. and Wanner, G.: Solving ordinary differential equations II, Springer, Berlin, 1996.

Heymsfield, A. J. and McFarquhar, G. M.: High albedos of cirrus in the tropical Pacific warm pool: Microphysical interpretations from CEPEX and from Kwajalein, Marshall Islands, J. Atmos. Sci., 53, 2424-2451, 1996.

Holton, J. R., Haynes, P. H., McIntyre, M. E., Douglass, A. R., Rood, R. B., and Pfister, L.: Stratosphere-troposphere exchange, Rev. Geoph., 33, 403-439, 1995.

Hudson, P. K., Shilling, J. E., Tolbert, M. A., and Toon, O. B.: Uptake of nitric acid on ice at tropospheric temperatures: Implications for cirrus clouds, J. Phys. Chem. A, 106, 9874-9882, 2002.

Hynes, R., Fernandez, M. A., and Cox, R. A.: Uptake of $\mathrm{HNO}_{3}$ on water-ice and coadsorption of $\mathrm{HNO}_{3}$ and $\mathrm{HCl}$ in the temperature range 210-235K, J. Geophys. Res., 107, 4797, doi: 10.1029/2001JD001 557, 2002.

Jacob, D. J., Field, B. D., Jin, E. M., Bey, I., Li, Q., Logan, J. A., Yantosca, R. M., and Singh, H. B.: Atmospheric budget of acetone, J. Geophys. Res., 107, 4100, doi:10.1029/2001JD000 694, 2002.

Jaeglé, L., Jacob, D. J., Wennberg, P. O., Spivakovsky, C. M., Hanisco, T. F., Lanzendorf, E. J., Hinsta, E. J., Fahey, D. W., Keim, E. R., Proffitt, M. H., Atlas, E. L., Flocke, F., Schauffler, S., McElroy, C. T., Midwinter, C., Pfister, L., and Wilson, J. C.:
Observed $\mathrm{OH}$ and $\mathrm{HO}_{2}$ in the upper troposphere suggest a major source from convective injection of peroxides, Geophys. Res. Lett., 24, 3181-3184, 1997.

Jaeglé, L., Jacob, D. J., Brune, W. H., and Wennberg, P. O.: Chemistry of $\mathrm{HO}_{\mathrm{x}}$ radicals in the upper troposphere, Atmos. Environ., 35, 469-489, 2001.

Jöckel, P., von Kuhlmann, R., Lawrence, M. G., Steil, B., Brenninkmeijer, C. A. M., Crutzen, P. J., Rasch, P. J., and Eaton, B.: On a fundamental problem in implementing flux-form advection schemes for tracer transport in 3-dimensional general circulation and chemical transport models, Q. J. R. Meteorol. Soc., 127, 1035-1052, 2001.

Johnson, D. E., Tao, W.-K., Simpson, J., and Sui, C.-H.: A study of the response of deep tropical clouds to large-scale thermodynamic forcings. Part I: Modeling strategies and simulations of TOGA COARE convective systems, J. Atmos. Sci., 59, 3492 3518, 2002.

Kalnay, E., Kanamitsu, M., Kistler, R., Collins, W., Deaven, D., Gandin, L., Iredell, M., Saha, S., White, G., Woollen, J., Zhu, Y., Chelliah, M., Ebisuzaki, W., Higgins, W., Janowiak, J., Mo, K. C., Ropelewski, C., Wang, J., Leetmaa, A., Reynolds, R., Jenne, R., and Joseph, D.: The NCEP/NCAR 40-year reanalysis project, Bull. Am. Met. Soc., 77, 437-471, 1996.

Kasting, J. F. and Singh, H. B.: Nonmethane hydrocarbons in the troposphere: Impact on the odd hydrogen and odd nitrogen chemistry, J. Geophys. Res., 91, 13 239-13 256, 1986.

Kondo, Y., Ziereis, H., ans S. Kawakami, M. K., Gregory, G. L., Sachse, G. W., Singh, H. B., Davis, D. D., and Merrill, J. T.: Reactive nitrogen over the Pacific Ocean during PEM-West A, J. Geophys. Res., 101, 1809-1828, 1996.

Kondo, Y., Koike, M., Kawakami, S., Singh, H. B., Nakajima, H., Gregory, G. L., Blake, D. R., Sachse, G. W., Merrill, J. T., and Newell, R. E.: Profiles and partitioning of reactive nitrogen over the Pacific Ocean in winter and early spring, J. Geophys. Res., 102, 28 405-28 424, 1997.

Kondo, Y., Toon, O. B., Irie, H., Gamblin, B., Koike, M., Takegawa, N., Tolbert, M. A., Hudson, P. K., Viggiano, A. A., Avallone, L. M., Hallar, A. G., Anderson, B. E., Sachse, G. W., Vay, S. A., Hunton, D. E., Ballenthin, J. O., and Miller, T. M.: Uptake of reactive nitrogen on cirrus cloud particles in the upper troposphere and lowermost stratosphere, Geophys. Res. Lett., 30, 1154, doi:10.1029/2002GL016 539, 2003.

Krueger, S. K. and Lazarus, S. M.: Intercomparison of multi-day simulations of convection during TOGA COARE with several cloud-resolving and single-column models, in: Preprints, 23rd Conf. on Hurricanes and Tropical Meteorology, Amer. Meteor. Soc., Dallas, TX, 1999.

Krueger, S. K., Fu, Q., Liou, K. N., and Chin, H.-N. S.: Improvements of an ice-phase microphysics parameterization for use in numerical simulations of tropical convection, J. Appl. Meteorol., 34, 281-287, 1995.

Laidler, K. J., Glasstone, S., and Eyring, H.: Application of the theory of absolute reaction rates to heterogeneous processes, J. Chem. Phys., 8, 659-667, 1940.

Landgraf, J. and Crutzen, P. J.: An efficient method for online calculations of photolysis and heating rates, J. Atmos. Sci., 55, 863878, 1998.

Lawrence, M. G., von Kuhlmann, R., Salzmann, M., and Rasch, P. J.: The balance of effects of deep convective mix- 
ing on tropospheric ozone, Geophys. Res. Lett., 30, 1940, doi:10.1029/2003GL017 644, 2003.

Lin, Y.-L., Farley, R. D., and Orville, H. D.: Bulk parameterization of the snow field in a cloud model, J. Climate Appl. Meteorol., 22, 1065-1092, 1983.

Lind, J. A. and Kok, G. L.: Henry's Law determinations for aqueous solutions of hydrogen peroxide, methylhydroperoxide, and peroxyacetic acid, J. Geophys. Res., 91D, 7889-7895, 1986.

Lord, S. J., Willoughby, H. E., and Piotrowicz, J. M.: Role of a parameterized ice-phase microphysics in an axisymmetric, nonhydrostatic tropical cyclone model, J. Atmos. Sci., 41, 2836-2848, 1984.

Lu, R., Lin, C., Turco, R., and Arakawa, A.: Cumulus transport of chemical tracers. 1. Cloud-resolving model simulations, J. Geophys. Res., 105, 10 001-10 221, 2000.

Lucas, C. and Orville, R. E.: TOGA COARE: Oceanic lightning, Mon. Weather Rev., 124, 2077-2082, 1996.

Mackerras, D.: Automatic short-range measurements of the cloud flash to ground flash ratio in thunderstorms, J. Geophys. Res., 90, 6195-6201, 1985.

Mackerras, D., Darveniza, M., Orville, R. E., Williams, E. R., and Goodman, S. J.: Global lightning: Total, cloud and ground flash estimates, J. Geophys. Res., 103, 19791-19809, 1998.

Mari, C., Jacob, D. J., and Bechtold, P.: Transport and scavenging of soluble gases in a deep convective cloud, J. Geophys. Res., 105, 22 255-22 267, 2000.

Mari, C., Saüt, C., Jacob, D. J., Ravetta, F., Anderson, B., Avery, M. A., Blake, D. R., Brune, W. H., Faloona, I., Gregory, G. L., Heikes, B. H., Sachse, G. W., Sandholm, S. T., Singh, H. B., Talbot, R. W., Tan, D., and Vay, S.: Sources of upper tropospheric $\mathrm{HO}_{\mathrm{x}}$ over the South Pacific Convergence Zone: A case study, J. Geophys. Res., 108, 8229, doi:10.1029/2000JD000 304, 2003.

Meier, A. and Hendricks, J.: Model studies on the sensitivity of upper tropospheric chemistry to heterogeneous uptake of $\mathrm{HNO}_{3}$ on cirrus ice particles, J. Geophys. Res., 107, 4696, 10.1029/2001JD000 735, 2002.

Meilinger, S. K., Tsias, A., Dreiling, V., Kuhn, M., Feigl, C., Ziereis, H., Schlager, H., Curtius, J., Sierau, B., Arnold, F., Zöger, M., Schiller, C., and Peter, T.: $\mathrm{HNO}_{3}$ partitioning in cirrus clouds, Geophys. Res. Lett., 26, 2207-2210, 1999.

Mlawer, E. J., Taubman, S. J., Brown, P. D., Iacono, M. J., and Clough, S. A.: Radiative transfer for inhomogeneous atmosphere: RRTM, a validated correlated-k model for the longwave, J. Geophys. Res., 102, 16 663-16682, 1997.

Orville, R. E., Zisper, E. J., Brook, M., Weidman, C., Aulich, G., Krider, E. P., Christian, H., Goodman, S., Blakeslee, R., and Cummins, K.: Lightning in the region of the TOGA COARE, Bull. Am. Met. Soc., 78, 1055-1067, 1997.

O'Sullivan, D. W., Lee, M. Y., Noone, B. C., and Heikes, B. G.: Henry's Law constant determinations for hydrogen peroxide, methyl hydroperoxide, hydroxymethyl hydroperoxide, ethyl hydroperoxide, and peroxyacetic acid, J. Phys. Chem., 100, 32413247, 1996.

Petersen, W. A., Rutledge, S. A., and Orville, R. E.: Cloud-toground lightning observations from TOGA COARE: Selected results and lightning location algorithms, Mon. Weather Rev., 124, 602-620, 1996.

Pierce, E. T.: Latitudinal variation of lightning parameters, J. Appl. Meteorol., 9, 194-195, 1970.
Popp, P. J., Gao, R. S., Marcy, T. P., Fahey, D. W., Hudson, P. K., Thompson, T. L., Kärcher, B., Ridley, B. A., Weinheimer, A. J., Knapp, D. J., Montzka, D. D., Baumgardner, D., Garrett, T. J., Weinstock, E. M., Smith, J. B., Sayres, D. S., Pittman, J. V., Dhaniyala, S., Bui, T. P., and Mahoney, M. J.: Nitric acid uptake on subtropical cirrus cloud particles, J. Geophys. Res., 109, D06 302, doi: 10.1029/2003JD004 255, 2004.

Prather, M. J. and Jacob, D. J.: A persistent imbalance in $\mathrm{HO}_{\mathrm{x}}$ and $\mathrm{NO}_{\mathrm{x}}$ photochemistry of the upper troposphere driven by deep tropical convection, Geophys. Res. Lett., 24, 3189-3192, 1997.

Prentice, S. A. and Mackerras, D.: The ratio of cloud to cloudground lightning flashes in thunderstorms, J. Appl. Meteorol., 16, 545-550, 1977.

Price, C. and Rind, D.: What determines the cloud-to-ground lightning fraction in thunderstorms?, Geophys. Res. Lett., 20, 463466, 1993.

Price, C., Penner, J., and Prather, M.: $\mathrm{NO}_{\mathrm{x}}$ from lightning: 1. Global distribution based on lightning physics, J. Geophys. Res., 102, 5929-5941, 1997.

Pruppacher, H. R. and Klett, J. D.: Microphysics of clouds and precipitation, Kluwer, Dordrecht, 1997.

Roehl, C. M., Nizkorodov, S. A., Zhang, H., Blake, G. A., and Wennberg, P. O.: Photodissociation of peroxynitric acid in the near-IR, J. Phys. Chem., 106, 3766-3772, 2002.

Rutledge, S. A., Williams, E. R., and Keenan, T. D.: The Down Under Doppler and Electricity Experiment (DUNDEE): Overview and preliminary results, Bull. Am. Met. Soc., 73, 3-16, 1992.

Salzmann, M.: Influences of deep convective cloud systems on tropospheric trace gases and photochemistry over the tropical West Pacific: A modeling case study, Ph.D. thesis, Johannes Gutenberg-Universität Mainz, Mainz, Germany, http://nbnresolving.de/urn/resolver.pl?urn=urn:nbn:de:hebis:77-9470, 2005.

Salzmann, M., Lawrence, M. G., Phillips, V. T. J., and Donner, L. J.: Modelling tracer transport by a cumulus ensemble: Lateral boundary conditions and large-scale ascent, Atmos. Chem. Phys., 4, 1797-1811, 2004.

Salzmann, M., Lawrence, M. G., Phillips, V. T. J., and Donner, L. J.: Model sensitivity studies regarding the role of the retention coefficient for the scavenging and redistribution of highly soluble trace gases by deep convective cloud systems., Atmos. Chem. Phys., 7, 2027-2045, 2007.

Sander, R., Kerkweg, A., Jöckel, P., and Lelieveld, J.: Technical note: The new comprehensive atmospheric chemistry module MECCA, Atmos. Chem. Phys., 5, 445-450, 2005.

Sander, S. P., Friedl, R. R., DeMore, W. B., Ravishankara, A. R., Golden, D. M., Kolb, C. E., Kurylo, M. J., Hampson, R. F., Huie, R. E., Molina, M. J., and Moortgat, G. K.: Chemical Kinetics and Photochemical Data for Use in Stratospheric Modeling Supplement to Evaluation 12: Update of Key Reactions, Evaluation 13, 00-3, Jet Propulsion Laboratory, Pasadena, California, 2000.

Schwartz, S. E.: Mass-transport considerations pertinent to aqueous phase reactions of gases in liquid-water clouds, Pages 415 471 of: Jaeschke, W. (ed.), Chemistry of Multiphase Atmospheric Systems, Springer-Verlag, Berlin and Heidelberg, Germany, 1986.

Schwartz, S. E. and White, W. H.: Solubility equilibria of the nitrogen oxides and oxyacids in dilute aqueous solution, in: Advances 
in Environmental Science and Engineering, edited by Pfafflin, J. R. and Ziegler, E. N., vol. 4, pp. 1-45, Gordon and Breach Science Publishers, NY, 1981.

Seinfeld, J. H. and Pandis, S. N.: Atmospheric Chemistry and Physics, Wiley and Sons, New York, 1998.

Singh, H., Chen, Y., Staudt, A., Jacob, D., Blake, D., Heikes, B., and Snow, J.: Evidence from the Pacific troposphere for large global sources of oxygenated organic compounds, Nature, 410, 1078-1081, 2001.

Singh, H. B. and Hanst, P. L.: Peroxyacetyl nitrate (PAN) in the unpolluted atmosphere - an important reservoir for nitrogen oxides, Geophys. Res. Lett., 8, 941-944, 1981.

Singh, H. B., Kanakidou, M., Crutzen, P. J., and Jacob, D. J.: High concentrations and photochemical fate of oxygenated hydrocarbons in the global troposphere, Nature, 378, 50-54, 1995.

Singh, H. B., Viezee, W., Chen, Y., Thakur, A. N., Kondo, Y., Talbot, R. W., Gregory, G. L., Sachse, G. W., Blake, D. R., Bradshaw, J. D., Wang, Y., and Jacob, D. J.: Latitudinal distribution of reactive nitrogen in the free troposphere over the Pacific Ocean in late winter/early spring, J. Geophys. Res., 103, 28 237-28 246, 1998.

Skamarock, W. C., Klemp, J. B., and Dudhia, J.: Prototypes for the WRF (Weather Research and Forecasting) model, in: Preprints, Ninth Conf. Mesoscale Processes, pp. J11-J15, Amer. Meteor. Soc., Fort Lauderdale, FL, 2001.

Snider, J. R. and Dawson, G. A.: Tropospheric light alcohols, carbonyls, and acetonitrile: Concentrations in the southwestern United States and Henry's law data, J. Geophys. Res., 90, 37973805, 1985.

Snider, J. R. and Huang, J.: Factors influencing the retention of hydrogen peroxide and molecular oxygen in rime ice, J. Geophys. Res., 103, 1405-1415, 1998.

Sommerfeld, R. A., Knight, C. A., and Laird, S. K.: Diffusion of $\mathrm{HNO}_{3}$ in ice, J. Geophys. Res., 25, 935-938, 1998.

Staudinger, J. and Roberts, P. V.: A critical review of Henry's law constants for environmental applications, Crit. Rev. Environ. Sci. Technol., 26, 205-297, 1996.

Stuart, A. L. and Jacobson, M. Z.: A timescale investigation of volatile chemical retention during hydrometeor freezing: Nonrime freezing and dry growth riming without spreading, J. Geophys. Res., 108, 4178, doi: 10.1029/2001JD001 408, 2003.

Stuart, A. L. and Jacobson, M. Z.: Chemical retention during dry growth riming, J. Geophys. Res., 109, D07 305, doi: 10.1029/2003JD004 197, 2004.

Su, H., Chen, S. Y. S., and Bretherton, C. S.: Three-dimensional week-long simulations of TOGA COARE convective systems using the MM5 mesoscale model, J. Atmos. Sci., 56, 2326-2344, 1999.

Tabazadeh, A. and Turco, R. P.: A model for heterogeneous chemical processes on the surfaces of ice and nitric acid trihydrate particles, J. Geophys. Res., 98, 12 727-12 740, 1993.

Tabazadeh, A., Toon, O. B., and Jensen, E. J.: A surface chemistry model for nonreactive trace gas adsorption on ice: Implications for nitric acid scavenging by cirrus, Geophys. Res. Lett., 26, 2211-2214, 1999.

Takemi, T. and Rotunno, R.: The effects of subgrid model mixing and numerical filtering in simulations of mesoscale cloud systems, Mon. Weather Rev., 131, 2085-2191, 2003.

Thompson, A. M., Johnson, J. E., Torres, A. L., Bates, T. S., Kelly,
K. C., Atlas, E., Greenberg, J. P., Donahue, N. M., Yvon, S. A., Saltzman, E. S., Heikes, B. G., Mosher, B. W., Shashkov, A. A., and Yegorov, V. I.: Ozone observations and a model of marine boundary layer photochemistry during SAGA 3, J. Geophys. Res., 98, 16955-16968, 1993.

Thompson, A. M., Witte, J. C., McPeters, R. D., Oltmans, S. J., Schmidlin, F. J., Logan, J. A., Fujiwara, M., Kirchhoff, V. W. J. H., Posny, F., Coetzee, G. J. R., Hoegger, B., Kawakami, S., Ogawa, T., Johnson, B. J., Vömel, H., and Labow, G.: Southern Hemisphere Additional Ozonesondes (SHADOZ) 1998-2000 tropical ozone climatology 1. Comparison with Total Ozone Mapping Spectrometer (TOMS) and ground-based measurements, J. Geophys. Res., 108, 8238, doi: 10.1029/2001JD000 967, 2003.

Tyndall, G. S., Cox, R. A., Garnier, C., Lesclaux, R., Moortgat, G. K., Pilling, M. J., Ravishankara, A. R., and Wallington, T. J.: Atmospheric chemistry of small organic peroxy radicals, J. Geophys. Res., 106, 12 157-12 182, 2001.

von Kuhlmann, R.: Photochemistry of tropospheric ozone, its precursors and the hydroxyl radical: A 3D-modeling study considering non-methane hydrocarbons, Ph.D. thesis, Johannes Gutenberg Universität Mainz, Mainz, Germany, 2001.

von Kuhlmann, R., Lawrence, M. G., Crutzen, P. J., and Rasch, P. J.: A model for studies of tropospheric ozone and nonmethane hydrocarbons: Model description and ozone results, J. Geophys. Res., 108, doi: 10.1029/2002JD002 893, 2003a.

von Kuhlmann, R., Lawrence, M. G., Crutzen, P. J., and Rasch, P. J.: A model for studies of tropospheric ozone and nonmethane hydrocarbons: Model evaluation and ozone-related species, J. Geophys. Res., 108, 4729, doi: 10.1029/2002JD003 348, 2003 b.

Wahner, A., Mentel, T. F., and Sohn, M.: Gas-phase reaction of $\mathrm{N}_{2} \mathrm{O}_{5}$ with water vapor: Importance of heterogeneous hydrolysis of $\mathrm{N}_{2} \mathrm{O}_{5}$ and surface desorption of $\mathrm{HNO}_{3}$ in a large teflon chamber, Geophys. Res. Lett., 25, 2169-2172, 1998.

Walcek, C. J.: Minor flux adjustment near mixing ratio extremes for simplified yet highly accurate monotonic calculation of tracer advection, J. Geophys. Res., 105, 9335-9348, 2000.

Wang, C. and Prinn, R. G.: On the roles of deep convective clouds in tropospheric chemistry, J. Geophys. Res., 105, 22 269-22 297, 2000.

Wang, Y. H., Liu, S. C., Wine, P. H., Davis, D. D., Sandholm, S. T., Atlas, E. L., Avery, M. A., Blake, D. R., Blake, N. J., Burne, W. H., Heikes, B. G., Sachse, G. W., Shetter, R. E., Singh, H. B., Talbot, R. W., and Tan, D.: Factors controlling tropospheric $\mathrm{O}_{3}$, $\mathrm{OH}, \mathrm{NO}_{\mathrm{x}}$, and $\mathrm{SO}_{2}$ over the tropical Pacific during PEM-Tropics B, J. Geophys. Res., 106, 32 733-32 747, 2001.

Webster, P. J. and Lukas, R.: TOGA COARE: The Coupled OceanAtmosphere Response Experiment, Bull. Am. Met. Soc., 73, 1377-1416, 1992.

Wicker, L. J. and Skamarock, W. C.: Time-splitting methods for elastic models using forward time schemes, Mon. Weather Rev., 130, 2088-2097, 2002.

Wollenhaupt, M. and Crowley, J. N.: Kinetic studies of the reactions $\mathrm{CH}_{3}+\mathrm{NO}_{2} \rightarrow$ products, $\mathrm{CH}_{3} \mathrm{O}+\mathrm{NO}_{2} \rightarrow$ products, and $\mathrm{OH}+\mathrm{CH}_{3} \mathrm{C}(\mathrm{O}) \mathrm{CH}_{3} \rightarrow \mathrm{CH}_{3} \mathrm{C}(\mathrm{O}) \mathrm{OH}+\mathrm{CH}_{3}$, over a range of temperature and pressure, J. Phys. Chem., 104, 64296438, 2000.

Wollenhaupt, M., Carl, S. A., Horowitz, A., and Crowley, J. N.: Rate coefficients for reaction of $\mathrm{OH}$ with acetone between 202 
and 395K, J. Phys. Chem., 104, 2695-2705, 2000.

Wu, X., Grabowski, W. W., and Moncrieff, M. W.: Long-term behavior of cloud systems in TOGA COARE and their interactions with radiative and surface processes. Part I: Two-dimensional modeling study, J. Atmos. Sci., 55, 2693-2714, 1998.

Wurzler, S.: The scavenging and wet deposition of nitrogen compounds by a warm convective cloud using two cloud dynamic models, Ph.D. thesis, Johannes Gutenberg Universität Mainz, Mainz, Germany, 1995.

$\mathrm{Xu}, \mathrm{K} .-\mathrm{M}$. and Krueger, S. K.: Evaluation of cloudiness parameterizations using a cumulus ensemble model, Mon. Weather Rev., 119, 342-367, 1991.

$\mathrm{Xu}, \mathrm{K} . \mathrm{M}$. and Randall, D. A.: Explicit simulation of cumulus ensembles with GATE phase III data: Comparison with observations, J. Atmos. Sci., 53, 3710-3736, 1996.

Yin, Y., Carslaw, K. S., and Parker, D. J.: Redistribution of trace gases by convective clouds - mixed phase processes, Atmos. Chem. Phys., 2, 293-306, 2002.

Zdunkowski, W. G., Panhans, W. G., Welch, R. M., and Korb, G. J.: A radiation scheme for circulation and climate models, Contributions to Atmospheric Physics, 55, 215-238, 1982.

Ziereis, H., Minikin, A., Schlager, H., Gayet, J. F., Auriol, F., Stock, P., Baehr, J., Petzold, A., Schumann, U., Weinheimer, A., Ridley, B., and Ström, J.: Uptake of reactive nitrogen on cirrus cloud particles during INCA, Geophys. Res. Lett., 31, L05 115, doi:10.1029/2003GL018 794, 2004.

Zondlo, M. A., Barone, S. B., and Tolbert, M. A.: Uptake of $\mathrm{HNO}_{3}$ on ice under upper tropospheric conditions, Geophys. Res. Lett., 24, 1391-1394, 1997. 